\title{
港湾の特性を考慮した大規模国際海上コンテナ 輸送ネットワーク上の船社の費用最小化モデル
}

\author{
柴崎 隆一 1 渡部 富博 2 家田 仁 3 \\ 1正会員 国土交通省 国土技術政策総合研究所 港湾研究部主任研究官 \\ ( (239-0826 神奈川県横須賀市長瀬三丁目1-1) \\ E-mail: shibasaki-r92y2@ysk.nilim.go.jp \\ 2正会員 国土交通省 国土技術政策総合研究所 港湾研究部港湾システム研究室長 \\ （干239-0826 神奈川県横須賀市長瀬三丁目 1-1） \\ E-mail: watanabe-t2w3@ysk.nilim.go.jp \\ 3正会員 東京大学教授 工学系研究科社会基盤学専攻（干113-8656 東京都文京区本郷七丁目3-1） \\ E-mail: ieda@civil.t.u-tokyo.ac.jp
}

\begin{abstract}
本研究は，我が国をはじめとする各国の港湾施策のインパクトを計測することを目的に，国際海上コン テナ輸送市場における, 外航コンテナ輸送船社による大規模ネットワーク上の輸送コスト最小化問題を扱 う. 具体的には, 最近の施策の焦点となっている, 船舶の大型化に対応するための大水深バースの整備や, 貨物が集中することによる港湾費用の低減および過度の集中による混雑を考慮した，外航船社の寄港地お よび輸送船舶サイズの決定モデルを構築するものである.

構築したモデルを, 東アジア地域を中心とした大規模国際海上コンテナ輸送ネットワークに適用し, モ デルの振る舞いが概ね妥当であり，また規模の経済・不経済に関連する感度分析の結果も概ね良好である ことを確認した。
\end{abstract}

Key Words : international maritime container shipping, cost minimization, multiple ocean-going carriers, network equilibrium assignment, large-scale network

\section{1. はじめに}

近年，中国をはじめとするアジア地域の急激な経済成 長に伴い，アジア地域を発着とする貿易や貨物量も急激 に増加している. 特に, 海上コンテナについてみれば, 中国をはじめとする各国・各港において大規模なコンテ ナターミナルの開発投資が行われ，港湾間・ターミナル 間競争が激しくなっていることも背景に，各港のコンテ ナ貨物取扱量の伸びは著しい. 表-1に示す2008年の世界 の海上コンテナ取扱量ランキング（上位30港）をみると, 上位8港をはじめ, 30港中21港がアジア地域の港湾であ ることがわかる．なかでも，中国の港湾が9港を数える ほか，ドバイ (アラブ首長国連邦) , クラン (マレーシ ア），ランチャバン（タイ）など, 中東や東南アジアの 港湾も取扱量を伸ばしている。，一方で，同じアジア地域 に属しながらも，日本の港湾（東京の24位が最高）や 2007年に上海港に抜かれ中国第1位の座を譲り渡した香 港なじ, 伝統的な港湾の中には地位が低下しつつあるも のも見られる.
このなかで，わが国を含め，韓国・中国・アセアン諸 国など東アジア地域の各国・各港湾は，ライバル港との 競争に打ち勝ち, あるいは遅れを取らないために，また 自国港湾の相対的な地位低下に伴い, 自国発着貨物の輸 送やひいては自国産業の国際競争力という観点から，不 利益をもたらさず逆に優位性を得るために，活発な投資 やさまざまな関連施策を実施している，たとえば我が国 では，2004年より3大湾6港を対象としたスーパー中枢港 湾施策が実施され，大型船の入港が可能な大水深岸壁の 整備, 取扱貨物量の増加・集中による単位貨物あたりの 港湾コストの削減, ターミナル内リードタイムの削減等 により, 国際貨物輸送費用の削減を通じて, 我が国産業 の国際競争力強化を目指寸ものとされている2).さらに 最近では, より一層の「選択と集中」をめざし, 国際コ ンテナ戦略港湾施策が進められている.

そこで本研究は，これらの施策が，東アジア圈におけ る国際海上コンテナ貨物の流動パターンや輸送費用にど のような影響を与えるかについて，定量的な検討が可能 となる貨物流動モデルを構築することを目的とする. 特 
表-1２008年の海上コンテナ取扱量ランキングリ

\begin{tabular}{|c|c|c|c|c|c|}
\hline $\begin{array}{l}2008 \\
\text { 順位 }\end{array}$ & $\begin{array}{l}2007 \\
\text { 順位 }\end{array}$ & 港湾名 & 国・地域 & $\begin{array}{c}\text { 2008年 } \\
\text { 取扱量 } \\
\text { (万TEU) }\end{array}$ & $\begin{array}{l}\text { 対前年 } \\
\text { 増加率 }\end{array}$ \\
\hline 1 & 1 & シンガポール & シンガポール & 2,992 & $7.1 \%$ \\
\hline 2 & 2 & 上海 & 中国 & 2,798 & $7.0 \%$ \\
\hline 3 & 3 & 香港 & 中国 & 2,425 & $1.0 \%$ \\
\hline 4 & 4 & 深圳 & 中国 & 2,141 & $1.5 \%$ \\
\hline 5 & 5 & 釜山 & 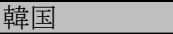 & 1,343 & $1.3 \%$ \\
\hline 6 & 7 & ドバイ & UAE & 1,183 & $11.1 \%$ \\
\hline 7 & 11 & 寧波・舟山 & 中国 & 1,123 & $20.0 \%$ \\
\hline 8 & 12 & 広州 & 中国 & 1,100 & $19.6 \%$ \\
\hline 9 & 6 & ロッテルダム & オランダ & 1,080 & $0.1 \%$ \\
\hline 10 & 10 & 青島 & 中国 & 1,032 & $9.1 \%$ \\
\hline 11 & 9 & ハンブルク & ドイツ & 970 & $-2.0 \%$ \\
\hline 12 & 8 & 高雄 & 台湾 & 968 & $-5.7 \%$ \\
\hline 13 & 14 & アントワープ & ベルギー & 866 & $5.9 \%$ \\
\hline 14 & 17 & 天津 & 中国 & 850 & $19.7 \%$ \\
\hline 15 & 16 & クラン & マレーシア & 797 & $11.9 \%$ \\
\hline 16 & 13 & ロサンゼルス & 米国 & 785 & $-6.1 \%$ \\
\hline 17 & 15 & ロングビーチ & 米国 & 649 & $-11.2 \%$ \\
\hline 18 & 18 & TJペラパス & マレーシア & 560 & $1.8 \%$ \\
\hline 19 & 20 & ブレーメン & ドイツ & 550 & $12.5 \%$ \\
\hline 20 & 19 & $\mathrm{NY} / \mathrm{NJ}^{* 1}$ & 米国 & 524 & $-1.1 \%$ \\
\hline 21 & 21 & ランチャバン & タイ & 513 & $10.6 \%$ \\
\hline 22 & 22 & 厦門 & 中国 & 503 & $8.6 \%$ \\
\hline 23 & 26 & 大連 & 中国 & 450 & $-1.5 \%$ \\
\hline 24 & 25 & 東京 & 日本 & 427 & $3.6 \%$ \\
\hline 25 & 23 & TJプリオク & インドネシア & 418 & $1.0 \%$ \\
\hline 26 & 24 & JNPT $^{* 2}$ & インド & 418 & $3.0 \%$ \\
\hline 27 & 29 & コロンボ & スリランカ & 369 & $9.2 \%$ \\
\hline 28 & 34 & バレンシア & スペイン & 359 & $18.1 \%$ \\
\hline 29 & 28 & 横浜 & 日本 & 349 & $1.7 \%$ \\
\hline 30 & 27 & ジョイアタウロ & イタリア & 347 & $0.6 \%$ \\
\hline
\end{tabular}

に，実際の国際海上コンテナ輸送ネットワークが全世界 的な規模で構築されていることを念頭に，東アジアを中 心とする大規模ネットワークを対象に，大水深バースの 整備や港湾における規模の経済が，国際海上コンテナ輸 送船社の配船パターン（寄港地，船舶サイズ）の決定に 与える影響が検討可能となるような，外航船社のコスト 最小化モデルを構築するものである．以下，2.で既往研 究のレビューと本研究の位置づけについて述べ，3.でモ デル構成を説明し，4.で入力データについて述べた後，

5.で実ネットワークへモデルを適用して，収束状況や再 現性といったモデルのパフォーマンスを確認し，6.で本 モデルで設定した規模の経済・不経済に関する感度を確 認し, 最後に7.で本研究の成果を取りまとめる.

\section{2. 既往研究のレビューと本研究の位置づけ}

従来，国際海上コンテナ輸送船社（以下外航船社）の 配船パターンを記述するモデルは，対象航路や港湾を絞 り, また港湾の条件（各種の港湾費用, 入港可能船舶サ イズ, 貨物輸送需要等) は固定して, 航路（ループ）ご との寄港地や船舶サイズを決定するものが多かった．な お, 最近の外航船社の行動モデルについては,
Christiansen et al. ${ }^{3 / 4)}$ によくまとめられている. Christiansen et al. ${ }^{3}$ にも述べられているように, 多くの研究は, 整数計 画法・線形計画法・動的計画法のような厳密解法, ある いはGA（遺伝的アルゴリズム）のようなヒューリステ イックな解法を用いて, 航路ごとの寄港地や船舶サイズ を決定するものである. Christiansen et al. ${ }^{3}$ 以降の研究例と しては, 東南アジア航路や北米航路を対象に, 整数計画 法等により最適船舶サイズを求めたもの スケジューリングの同時決定問題についてヒューリステ イックな解法を提案し，アジア〜欧州航路に適用したも の》，アジア発着各航路の寄港地選択問題を厳密解法に よって解いたもの $)^{8}$, 空コンテナを考慮した寄港地選択 問題をGAによって解いたもの9)，などがあげられる．こ れらの研究では, 主に計算が煩雑になるという理由によ り，モデル化の対象とする航路や港湾は限定され，また 港湾取扱量や入出港船舶数の増減に伴う費用の変化が内 生化されることも，ほとんどなかった，さらに，入港可 能な船舶のサイズについてもアプリオリに与えられるの みで, 水深別のバース数やバース数の不足による混杂隹, さらには船社を跨いだこれらの影響等が考慮されること はほほとんどなかった。

一方で, Haralambides ${ }^{10}$ は, 国際海上コンテナ輸送のモ デル構築を難しくしている最大の要因は, 船舶に積まれ るコンテナにとっての最適解が，船舶のそれとは一致し ない点にあると指摘している. 寸なわち, モデル構築の 観点からすれば, 船舶とコンテナのいずれかに重点を置 く必要があり，この文脈で整理すれば，ここまでに例示 した研究はすべて, 船舶にとっての最適行動をモデル化 するものと位置づけられる.

そこで本研究では, 実際の東アジア圈の大規模な国際 海上コンテナ輸送ネットワークに適用可能となることを 念頭に, 各港湾の水深別バース数や, 1 ターミナルあた りの取扱量の増加に伴う単位貨物あたりの港湾費用の逓 減効果（港湾における規模の経済），あるいは入出港船 舶の集中による混雑や荷役時間の増大（規模の不経済） を明示的に考慮した, 外航船社の費用最小化モデルを構 築する. 具体的には，上記の要素を考慮する代わりに， コンテナの最適解を求めるとの立場から, 船舶の制約 (入出港船舶数が一致するという制約）を緩和し，ネッ トワーク均衡配分手法を応用したモデルを構築するもの である.ここで, 複数の船社がそれぞれ最適化行動を行 うと仮定するものの，公共バースを想定した港湾内にお いては，規模の経済の発揮や混雑などを通じて相互の費 用関数に影響を及ぼしあうことを考慮するため，相互干 渉つきの配分問題として，本モデルを取り扱う.

これまで筆者ら ${ }^{11), 12}$ は，上記の立場から，外航船社の 輸送費用最小化モデルを構築してきた. ただし，これら のモデルは，港湾における規模の経済・不経済を考慮し 
ないなど，コスト関数の設定に関する検討が不十分であ った. また，バースの大水深化や港湾の規模の経済が, 外航船社の配船パターンや港湾取扱量にどのような影響 を与えるかなど，モデルのパフォーマンスについての検 討も不十分であった。本研究は，既存研究の成果を参考 としつつも，上記の課題を克服し，またネットワーク構 成や入力データ等についても大幅に見直すことで，モデ ルの整合性を向上させ，多様な政策変数を含みかつ大規 模ネットワークに適用可能なツールとして，実用的なモ デルを構築するものである.

なお，現実の国際海上コンテナ輸送市場をより実際的 に再現するためには，外航船社の行動原理としては，利 潤の最大化（すなわち，運顀の決定メカニズム）を考慮 する必要があり，また荷主やフォワーダーの行動につい ても考慮する必要がある。これらの要素を考慮した総合 的なモデルの構築は, 別稿 ${ }^{13)}$ に譲る.

\section{3. モデルの構成}

\section{(1) 概要}

各船社が，自社の港湾間貨物輸送需要（港湾間 OD） を所与として，コンテナの総輸送費用を最小化するよう 行動するという本研究の想定する枠組に基づき, 本モデ ルの目的関数を，図-1 に示すような国際海上コンテナ 輸送ネットワークにおいて, 各リンクのフロー（コンテ ナフロー）を決定する問題として式(1)-(4)の通り定義す る.

$$
\min _{x}\left\{\sum_{v \in V} x_{v g} \cdot t_{v g}\left(x_{11}, \cdots, x_{v g}, \cdots, x_{|V||G|}\right)\right\}, \quad \forall g \in G
$$

$$
\begin{array}{cc}
\text { s.t. } \sum_{k \in K_{a g}} f_{a k g}-q_{a g}=0 & \forall a \in A \\
x_{v g}=\sum_{k \in K_{a g}} \sum_{a \in A} \delta_{a g k}^{v} \cdot f_{a k g} & \forall v \in V \\
f_{a k g} \geq 0, x_{v g} \geq 0 &
\end{array}
$$

ここで, $x_{v g}$ : 船社 $g$, リンク $v$ のコンテナフロー, $t_{v g}\left(x_{11}, \cdots, x_{v g}, \cdots, x_{|V||G|}\right):$ グループ $g$, リンク $v$ のコンテナ 1 TEU（20フィート換算コンテナ個数）あたりのコスト, $G$ : 船社の集合, $|G|$ : 船社数, $V$ : リンクの集合, $\mid V$ : リン

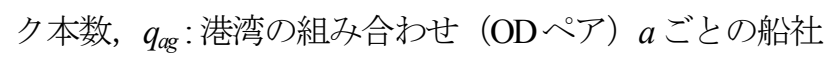
別貨物輸送需要, $f_{a k g}$ : ODペア $a$ のパス $k$ の経路交通量, $K_{a g}$ : ODペア $a$ の経路集合, $P$ : 港湾の集合, $\delta_{a g k}^{v}$ : クロネ ッカーのデルタ (ODペア $a$ のパス $k$ にリンク $v$ が含ま れるとき 1 ，含まれないとき 0) である. 図-1 に示され るネットワークにおいて, 連結されたリンク同士では, コンテナフローの保存則が成立している，また，各リン クが船舶サイズ別に設定されていることにより，リンク フローの決定問題が，各港の入出港コンテナ貨物量等だ けでなく，船舶サイズの決定問題も内包している. 式(1)-(4)は，筆者らによる既往の研究 11), 12)において, 「船社ごとのシステム最適配分」（Group-based System Optimum）と定義した配分に相当するものである.ここ で，リンクコスト関数 $t_{\mathrm{g}}$ が，同じ船社の他のリンクフ ロー $x_{v^{\prime} g}, \forall v^{\prime} \in V$ や，他船社のリンクフロー $x_{v g^{\prime}}, \forall g^{\prime} \in G$ にも依存するものとして，定義されることに注意された い. このようにコストが他船社のフローに依存し，また 国際海上コンテナ輸送市場（特に長距離航路）が寡占的 である現状も鑑みれば，本研究で取り扱う問題は，クー ルノー・ナッシュ（CN）プレーヤー存在下におけるネ

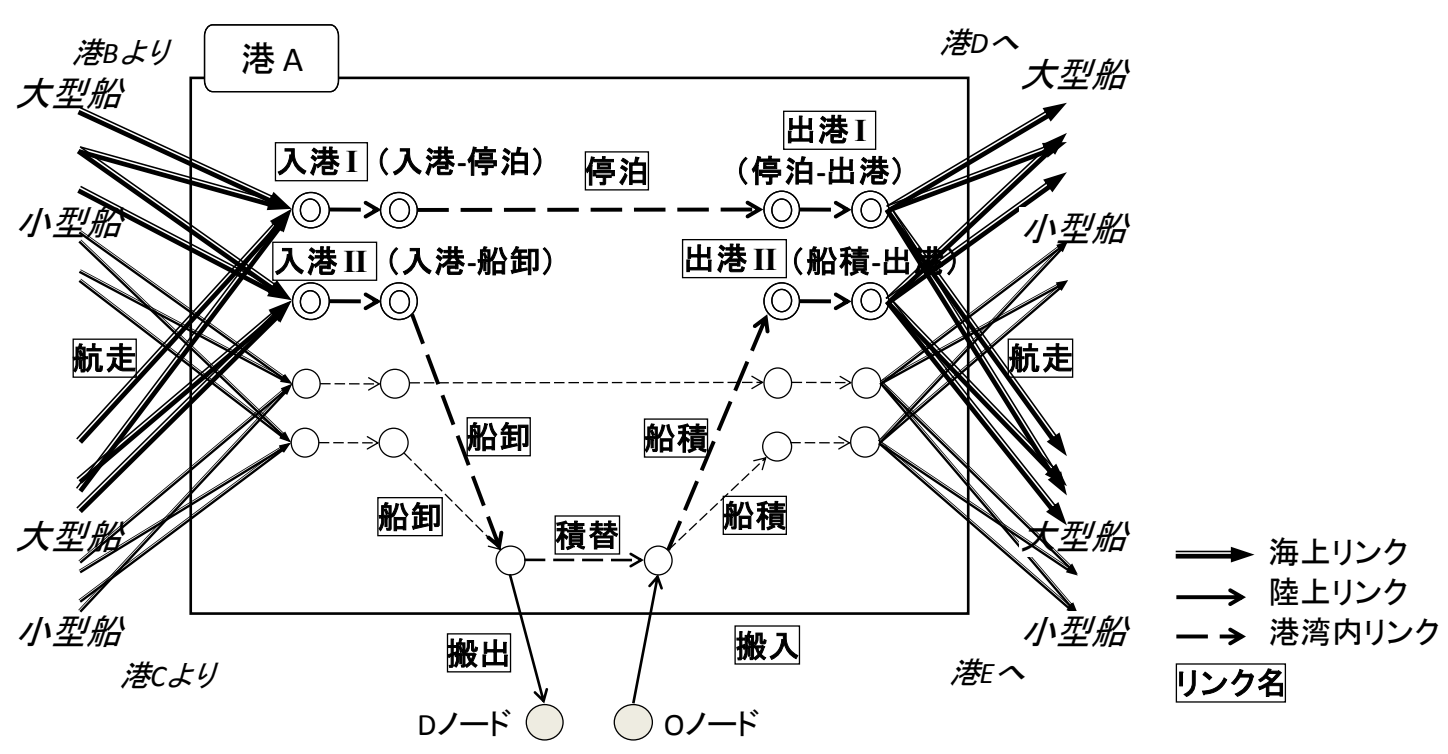

図-1 モデルのネットワーク構成 
ットワーク均衡配分問題 ${ }^{14)}$ 15)の一種と捉えることもでき よう.

以下で, 各リンクの概要, および設定したコスト関数 について順番に説明し，本章の最後で，モデルの解法に ついて述べる. 各リンクのコスト関数は, 基本的に, い わゆる一般化費用で定義され，各リンクに関係する金銭 費用と所要時間に関するコスト（金銭時間換算係数と所 要時間の積）の和で表される．ここで，金銭費用だけで なく時間に関するコストも含めるのは，船社の行動原理 を幅広く表現するためである，すなわち，金銭時間換算 係数が十分に小さいときは金銭費用が重視され，大きい ときは所要時間が重視されることとなる ${ }^{1}$. なお，5.の モデルパフォーマンスの検証においては，この金銭時間 換算係数を変化させたときの出力の相違についても検討 する.

\section{(2) 航走リンク}

すべての港湾の組み合わせについて結ばれる，海上輸 送リンクである. 船舶サイズ別に設定されており，通過 したリンクによって, 輸送船舶サイズが表現される.

航走リンクはさらに，サービス頻度（貨物の期待出港 待ち時間）に関わる項の考慮の有無により, 以下の 4 種 類に分けられる. 寸なわち, (i)停泊-航走-停泊リンク （前後どちらの港においても積卸されず，船舶に積まれ たままとなるコンテナ)，(ii)停泊-航走-船卸リンク（出 発港では船舶に積まれたままであるが，到着港では船卸 されるコンテナ)，(iii)船積-航走-停泊リンク（(ii)の逆）， (iv)船積-航走-船卸リンク（出発港で船積され, 到着港で 船卸されるコンテナ）である ${ }^{2}$. 貨物が当該港で船積・ 船卸される際は, 海上輸送時間に加え, 船積されるまで の期待待ち時間を考慮する。一方，貨物が当該港におい て船に積まれたまま停泊している場合は，荷役に要する 時間だけ停泊したあと直ちに出港するため, 出港までの 待ち時間は考慮しない.ここで，コスト関数の対称性を 確保するため, 待ち時間を船積時と船卸時に均等に課す ものとする.

このとき, 航走リンクのコスト関数は, 以下の式で表 される.

$$
G C R_{m v g}=\frac{C C R_{w g}}{l f_{i j w g} \cdot c a p_{w}} \cdot \frac{l_{i j}}{v l_{w}}+v t_{g} \cdot\left\{\frac{l_{i j}}{v l_{w}}+\beta_{m} \cdot \frac{l f_{v g} \cdot c a p_{w}}{2 \cdot \sum_{m} X C_{m v g}}\right\}
$$

ここで, $m:$ 航走リンクの種別を表す係数 $(m=1, \cdots, 4)$, $w$ : 船舶サイズ $(w \in W, W$ は船舶サイズの集合）， $i, j:$

1前者は船社の都合を優先し, 後者は荷主の意向を重視した行動原 理と解釈することもできる.

2なお以下では，この 4 種類の航走リンクを，それぞれ，航走 I・ II・IIIIVリンクと呼ぶことがある.
起点港および終点港 $(i, j \in P, P$ は港湾の集合）, $G C R_{m y}$ : 航走リンク $v(=\ddot{j} w)$ の $1 \mathrm{TEU}$ あたりコスト（円 TEU)， $C C R_{\text {ng }}$ : 単位時間あたり航行時船舶費用（円/時/ 隻)， $l f_{\text {jing }}$ : ロードファクター (消席率),$c a p_{w}$ : 船のキ ヤパシティ (TEU/隻),$v t_{g}$ : 金銭時間換算係数（船社の 時間価値，円/時/TEU）， $l_{i j}$ : 港湾間距離（海里）, $v_{\mathrm{w}}$ : 船速（ノット二海里時）， $\beta_{m}$ : 航走リンクフローの種類 別に設定される係数（航走 I リンクのとき $\beta_{1}=0$, 航走 IV リンクのとき $\beta_{4}=1$, 航走 II ・ III リンクのとき $\beta_{2}=\beta_{3}=$ 1/2),$X C_{m \mathrm{mg}}$ :リンクフロー（TEU/時）である.

式(5)右辺第 1 項は，海上輸送に関わる $1 \mathrm{TEU}$ あたりの 金銭費用を表す，4 章図-5 にも示されるように，船舶が 大型化するほど，費用は低減する，第 2 項は時間費用で あり，海上輸送時間と期待待ち時間の和に，金銭時間換 算係数を乗じている. このうち貨物の期待待ち時間は, 1 隻あたりのコンテナ輸送容量 $f_{v g} \cdot c a p_{w}$ を，単位時間あ たり実輸送量 $\sum_{m} X C_{m v g}$ で除することで得られる, 運航間 隔に関寸る関数で表される。ここで，1 隻の船に積卸港 湾が様々であるコンテナが積載されている現況を踏まえ, 単位時間あたり輸送量は，4 種類の航走リンクフローの 合計値となっている．式(5)より，リンクフローが増加 寸るほど運航間隔が狭まり, 期待待ち時間が低減するこ とがわかる．また，フローが同じ場合は，船舶が大型化 すると待ち時間は増加する.

\section{（3） 入港リンク・出港リンク}

各港湾における船舶の入出港を表現し, 港湾費用のう ちの入出港費用，および船舶の入出港時における混雑 (待ち時間) を考慮するリンクである. 航走リンクと同 様に, 船舶サイズごとに設定される. また, 航走リンク を 4区分したのと同様に，港湾内で荷役されるか㧵かに よって，入港リンクは，(i)入港-停泊リンク（入港 Iリン ク）と(ii)入港-船卸リンク（入港 II リンク）に, 出港リ ンクは, (iii)停泊-出港リンク（出港 Iリンク）と(iv)船積出港リンク（出港 II リンク）に分けられる. ただし, それぞれのコスト関数は同一である. また，どの船社も 利用可能な公共バースの利用を想定していることから， 他船社の入出港フローにも影響される.

以下では，入港リンクのコストを例に，コスト関数に ついて述べる.

$$
G A R_{v g}=\frac{C A D_{i w} / 2+C P A_{w g} \cdot T W A_{i w}}{\overline{l f a_{i w g}} \cdot c a p_{w}}+v t_{g} \cdot T W A_{i w}
$$

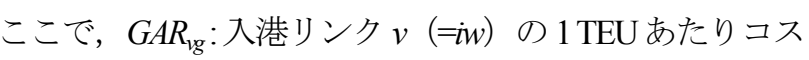
卜（円/TEU），CAD $D_{i w}: 1$ 隻あたり入出港費用（円/隻）, $C P A_{w g}$ : 単位時間あたり停泊時船舶費用（円/時/隻）, $\overline{l f a_{i w g}}$ : 港湾 $i$ に入港寸るサイズ $w$, 船社 $g$ の船舶の平均 消席率， $T W A_{i w}$ : 船混みによる船舶の平均入港待ち時間 
(時)である.

式(6)右辺第 1 項に示される金銭費用は，1隻あたりの 入港費（入出港費の半分）および停泊時費用の和を，1 隻あたりのコンテナ輸送量で除することで得る.ここで 平均消席率 $\overline{l f a_{i v g}}$ は, 以下に示すように, 各航走リンク の消席率 $l f_{i w n g}\left(i^{\prime \prime}\right.$ は直前の寄港地）の重みつき平均とし て表される.

$$
\overline{l f a_{i w g}}=\frac{\sum_{m} \sum_{i^{\prime}}\left\{X C_{m i^{\prime} i w g} \cdot l f_{i^{\prime} i w g}\right\}}{\sum_{m} \sum_{i^{\prime}} X C_{m i^{\prime} w g}}
$$

また式(6)右辺第 2 項に示される時間費用は，船舶の入 港待ち混雑によるものである. ここで, 待ち時間 $T W A_{i w}$ は, 待ち行列理論等から算出寸るのではなく, 計算の簡 便のため, 式(8)に示されるべき乗形の関数で表現する.

$$
T W A_{i w}=\gamma_{1} \cdot\left\{\varphi\left(N V A_{i w}, T U_{i w}, N B_{i u}^{-1}\right)\right\}^{2}
$$

ここで， $\gamma_{1}, \gamma_{2}$ : 船舶の入出港待ち時間関数に関するパラ メータ, $N V A_{i w}$ ：単位時間あたりの入港隻数（隻/時）,

$T U_{i w}: 1$ 隻あたりの船卸荷役時間（時/隻），NB 水深力テゴリ $u$ のバース数, $\varphi($.$) : バース処理能力に関す$ る関数である.

このうち入港隻数 $N V A_{i w}$ は, 以下のように表される.

$$
N V A_{i w}=\sum_{g \in G}\left(\frac{X A P_{i w g}+X A U_{i w g}}{\overline{l f a_{i w g}} \cdot c a p_{w}}\right)
$$

ここで, $X A P_{\text {ing }} X A U_{\text {ing }}$ : 入港 I および II リンクのフロー

（TEU/時）である． $N V A_{i w}$ は，公共バースを想定し，全 船社の合計值として定義されている.

また船卸荷役時間 $T U_{i w}$ は，以下の式で表される.

$$
T U_{i w}=T A R_{i w}+\frac{\overline{l f a g_{i w}} \cdot \operatorname{cap}_{w}}{\operatorname{prod}_{i} \cdot N C_{i w}} \cdot \frac{\sum_{g} X A U_{i w g}}{\sum_{g} X A U_{i w g}+\sum_{g} X A P_{i w g}}
$$

ここで, $T A R_{i w}$ : 入港時に最低限必要な時間（時）, $\overline{l f a g_{i w}}$ : 港湾 $i$ に入港寸る船舶サイズ $w$ の船舶の平均消席率,

$\operatorname{prod}_{i}: 1$ クレーンあたりの荷役効率（プロダクティビテ

イ, TEU/時)， $N C_{i w}$ : 1 隻あたりの使用クレーン数であ

る. なお $\overline{\text { lfag }_{i w}}$ は, 式(7)と同様の考え方により,

$$
\overline{\text { lfag }_{\text {iw }}}=\frac{\sum_{m} \sum_{g} \sum_{i^{\prime}}\left\{X C_{m^{\prime} i^{\prime} w g} \cdot l f_{i^{\prime} w g}\right\}}{\sum_{m} \sum_{g} \sum_{i^{\prime}} X C_{m i^{\prime} i w g}}
$$

と表される. 式(10)は，1 隻あたりの荷役時間が，入港 時にパイロットや接岸作業等で最低限必要な時間 $T A R_{i w}$ と，荷役個数に比例する荷役作業時間の和であることを 意味している.ここで荷役作業時間は，1 隻あたりの平

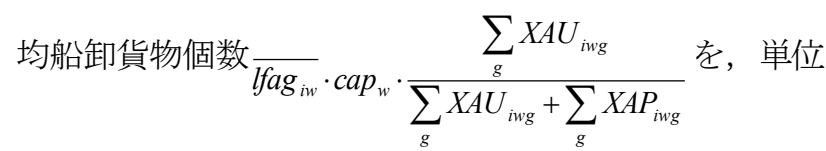
時間・1 バースあたりの処理能力 $\operatorname{prod}_{i} \cdot N C_{i w}$ で除するこ
とで得ている.

なお式(8)において，バース処理能力に関する関数を 明確化せず $\varphi\left(N V A_{i w}, T U_{i w}, N B_{i u}{ }^{-1}\right)$ と記述したのは, 状況に よって関数形が異なると考えられるためである. 具体的 には，バースの水深ランクとサイズ別の入港船舶数が, 1 対 1 関係ではないことに起因する. 寸なわち，大水深 のバースには，大型・小型のサイズを問わず船舶が入港 可能であるが，水深が浅いバースには，小型船舶しか入 港できない. このため, 大型バースの方が小型バースよ りも相対的に混雑している場合には，大型船は大型バー ス，小型船は小型バースに入港し，両バースの混雑度は 異なる。一方，小型バースの方が相対的に混雑している 場合は，混雑が均等化されるように一定割合の小型船が 大型バースを利用し，結果として両バースの混雑待ち時 間は等しくなると想定する. このような場合分けを考慮 した，具体的なコスト関数の設定方法については，付録 Aを参照されたい.

出港リンクコストについても, 同様に定義される.

$$
G D E_{v g}=\frac{C A D_{i w} / 2+C P A_{w g} \cdot T W D_{i w}}{\overline{l f d_{i v g}} \cdot c a p_{w}}+v t_{g} \cdot T W D_{i w}
$$

ここで, $G D E_{\text {g }}$ :出港リンクv (=iw) $1 \mathrm{TEU}$ あたりコスト

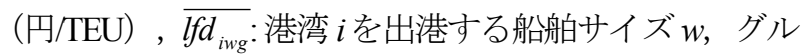
一プ $\mathrm{g}$ の船舶の平均消席率， $T W D_{i w}$ : 船混みによる船舶 の平均出港待ち時間（時）であり，それぞれ以下で表さ れる。

$$
\begin{gathered}
\overline{l f d_{i w g}}=\frac{\sum_{m} \sum_{i^{\prime}}\left\{X C_{m i i^{\prime} w g} \cdot l f_{i i^{\prime} w g}\right\}}{\sum_{m} \sum_{i^{\prime}} X C_{m i i^{\prime} w g}} \\
T W D_{i w}=\gamma_{1} \cdot\left\{\varphi\left(N V D_{i w}, T L_{i w}, N B_{i u}^{-1}\right)\right\}^{\gamma_{2}}
\end{gathered}
$$

ここで，NVD $D_{i w}$ ：単位時間あたりの出港隻数（隻/時）, $T L_{i w}: 1$ 隻あたりの船積荷役時間（時/隻）であり，

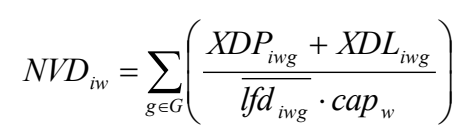

ただし， $X D P_{\text {iwg, }} X D L_{\text {ing }}$ : 出港 I・II リンクのフロー（TEU/ 時),

$$
T L_{i w}=T D E_{i w}+\frac{\overline{l f d g_{i w}} \cdot c a p_{w}}{\operatorname{prod}_{i} \cdot N C_{i w}} \cdot \frac{\sum_{g} X D L_{i w g}}{\sum_{g} X D L_{i w g}+\sum_{g} X D P_{i w g}}
$$

ただし，TDE $E_{i w}$ :出港時に最低限必要な時間（時）, $\overline{l f d g_{i w}}$ : 港湾 $i$ を出港する船舶サイズ $w$ の船舶の平均消席率であ り,

$$
\overline{l f d g_{i w}}=\frac{\sum_{m} \sum_{g} \sum_{i^{\prime}}\left\{X C_{m i^{\prime} w g} \cdot l f_{i^{\prime} w g}\right\}}{\sum_{m} \sum_{g} \sum_{i^{\prime}} X C_{m i i^{\prime} w g}}
$$




\section{(4) 停泊リンク}

入港 I リンクと出港 I リンクを結ぶリンクであり, 船 舶サイズごとに設定される. コスト関数として，停泊中 の船舶費用，およびその他の時間費用を考慮する．また 荷役時間は, 船社別の船卸に要寸る時間 $T U G_{\text {ivg }}$ と, 船 積に要する時間 $T L G_{i v g}$ から成る.

$$
\begin{aligned}
& G P A_{v g}=\left(\frac{T U G_{i w g}}{\overline{l f a_{i w g}} \cdot c a p_{w}}+\frac{T L G_{i w g}}{\overline{l f d_{i w g}} \cdot c a p_{w}}\right) \cdot C P A_{w g} \\
& +v t_{g} \cdot\left(T U G_{i w g}+T L G_{i w g}\right)
\end{aligned}
$$

ここで, $G P A_{\text {vg }}$ :停泊リンク $v(=i w)$ の $1 \mathrm{TEU}$ あたりコス 卜 (円/TEU) ,

$$
\begin{gathered}
T U G_{i w g}=T A R_{i w}+\frac{\overline{l f a_{i w g}} \cdot c a p_{w}}{\operatorname{prod}_{i} \cdot N C_{i w}} \cdot \frac{X A U_{i w g}}{X A U_{i w g}+X A P_{i w g}} \\
T L G_{i w g}=T D E_{i w}+\frac{\overline{l f d_{i w g}} \cdot c a p_{w}}{\operatorname{prod}_{i} \cdot N C_{i w}} \cdot \frac{X D L_{i w g}}{X D L_{i w g}+X D P_{i w g}}
\end{gathered}
$$

である.

\section{（5）船卸リンク・船積リンク}

船卸リンクは，各サイズの入港 II リンクと，搬出リ ンクおよび積替リンクを結ぶ。船積リンクは，搬入リン クおよび積替リンクと，各サイズの出港 II リンクを結 ぶ、いずれも，船舶サイズごとに設定される．コスト関 数は, 船卸・船積に要する時間に関係する費用 (停泊中 の船舶費用およびその他の費用）に加え，ターミナルの 利用に伴う費用（ターミナル費）を考慮する.

$$
\begin{aligned}
& G U L_{v g}=\left(\frac{\sum_{u} N B_{i u} \cdot C T E_{i}}{X T_{i}}+\frac{C P A_{w g}}{l f a_{i w g} \cdot c a p_{w}} \cdot T U G_{i w g}\right) \\
& +v t_{g} \cdot T U G_{i w g}
\end{aligned}
$$

ここで，GUL $L_{\mathrm{g}}$ : 船卸リンク $v(=i w)$ の $1 \mathrm{TEU}$ あたりコ スト（円/TEU），CTE : 単位時間あたりターミナル費用 （円/時/バース）， $X T_{i}$ : 下式で定義される港湾 $i$ の総取扱 量（TEU/時）である.

$$
X T_{i}=\sum_{g} \sum_{w} X A U_{i v g}+\sum_{g} \sum_{w} X D L_{i w g}
$$

本リンクでは，取扱量によらず予め決められている 1 バースあたりの固定的な施設利用料を，ターミナル費 $C T E_{i}$ と定義し，パイロットやタグボート，入港手続き費 用等といった船舶 1 隻あたりの費用として定義される入 出港費用 $C A D_{i w}$ ((3)の入港・出港少ンクに含まれる）や, 貨物 1 個を取り扱うごとに発生する荷役費用 $C H A_{i}((6)$, (7)の積替・搬出・搬入リンクに含まれる）と区別する.
本モデルにおいて，各リンクコスト関数は $1 \mathrm{TEU}$ あたり のコストとして定義されるため, $1 \mathrm{TEU}$ あたりターミナ ル費用についてみれば，取扱量が増えるほど費用が減少 するという，規模の経済が働くことになる.

船積リンクについても，同様の考え方により，コス 卜関数を設定する.

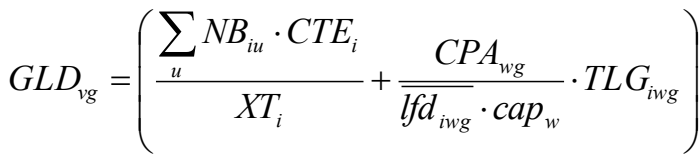

$$
\begin{aligned}
& +v t_{g} \cdot T L G_{i w g}
\end{aligned}
$$

ここで, $G L D_{v g}$ : 船積リンク $v(=i w)$ の $1 \mathrm{TEU}$ あたりコ スト（円/TEU）である.

\section{（6）積替リンク}

船卸リンクと船積リンクを結ぶ．各港湾に 1 本ずつ設 定される.

$$
G T R_{v g}=1.5 \cdot C H A_{i}+v t_{g} \cdot T T R_{i}
$$

ここで, GTR $R_{v g}$ 積替リンク $v(=i)$ の $1 \mathrm{TEU}$ あたりコス 卜 (円/TEU),$C H A_{i}$ : 搬出・搬入貨物の $1 \mathrm{TEU}$ あたり荷 役費用 (円/TEU) , TTR : 積替作業時間（時）である. なおここで，積替貨物の荷役費用は，港湾投資の評価に 関する解説書 ${ }^{16}$ の記述等に基づき，搬出・搬入貨物の荷 役費用の 1.5 倍と想定している.

\section{(7) 搬出リンク・搬入リンク}

搬出リンクは，船卸リンクと D ノードを結ぶ。搬入 リンクは，O ノードと船積リンクを結ぶ，各港湾にそれ ぞれ1本ずつ設定される.

$$
G O_{v g}=G D_{v g}=C H A_{i}
$$

ここで，GO (円/TEU)， $G D_{\mathrm{g} g}$ : 搬入リンク $v$ の $1 \mathrm{TEU}$ あたりコスト (円/TEU) である.

\section{(8) モデルの解法}

式(1)-(4)に示される問題は，既往研究 ${ }^{14)}$, 15) において示 される CN プレーヤー存在下におけるネットワーク均衡 配分問題と同様に，リンク間の相互干渉のある均衡配分

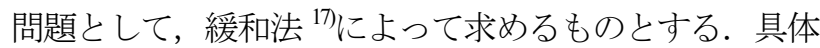
的な手順は，以下のとおりである。

Step 0. $n=0$ とし, 初期フロー $\left\{x_{v g}^{(0)}\right\}$ (求め方は 4.(5)参照)

に対するリンクコストを求める．ただし，式(20), (22)に含まれる $X T_{i}$ については，より信頼度の高 い実績值を代入する（4.(6)参照）.

Step $1 . n=n+1$ 
Step 2. 自社 $g$ 以外の各船社 $g^{\prime}\left(g, g^{\prime} \in G, g \neq g^{\prime}\right)$ のフロ 一を 1 期前のフロー $\left\{x_{v g^{\prime}}^{(n-1)}\right\}$ に固定して, 自社の費用 最小化問題を解く. 寸なわち,

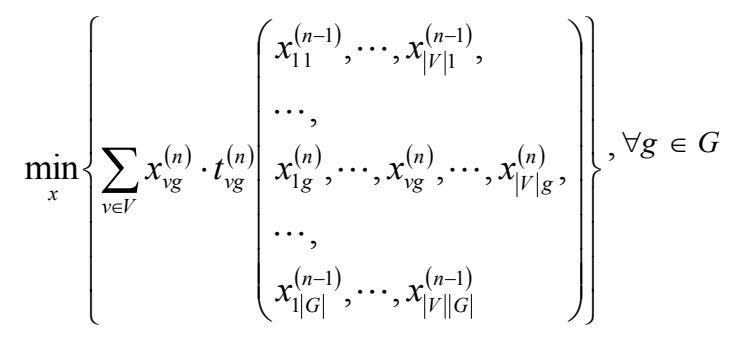

これを，全船社について行う。

Step 3. Step 2 で得られたフロー $\left\{x_{v g}^{(n)}\right\}$ 在 1 期前のフロー $\left\{x_{v g}^{(n-1)}\right\}$ と比較し, 収束 $\left({ }_{\Delta_{g}^{(n)}}=\frac{\sqrt{\sum_{v}\left\{x_{v g}^{(n)}-x_{v g}^{(n-1)}\right\}^{2}}}{\sum x_{v g}^{(n)}}<\varepsilon_{C}{ }^{\prime}\right.$ $\forall g \in G, \varepsilon_{C}$ は収束判定基準となる微小な正の数）し ているか, 繰り返し回数 $n$ が上限值に達していれば 終了，収束していなければ，Step 1へ戻る.

なお，航走リンクや船積・船卸リンクのように，リン クコストが，フローに対して反比例の関係（すなわち， 規模の経済が働いている状況）となっているリンクもあ ることから，ネットワーク均衡配分計算上の凸性が保証 されず, 得られる解は局所解であり, 最適解とは限らな い，そのため，本モデルにおいては，現状のリンクフロ 一を初期值として与え，これを起点に配分計算を行うこ とで，現状を出発点とした場合の（現状の近傍にある） 最適解を得るものと位置づけられる.

\section{4. 入カデータの準備}

本章では，本モデルの計算にあたって必要な，入力デ 一タの作成方法について述べる. 前章に示した変数のう ち, 外生的に与える必要のある変数を表-2 に整理した。 このうち，金銭時間換算係数 $v t_{g}$ につては，実績に基 づき適切な值を設定することが困難であるため，次章に おいて感度分析を行うものとする．また，計算対象とす る年次は, 港湾間貨物需要作成の基礎となる日本の全国 輸出入コンテナ貨物流動調査 ${ }^{18)}$ の調查年である, 2003 年を基準とした.

\section{（1）対象港湾}

多くの港湾を含むことが可能という本モデルの特徵を ふまえ，図-2 に示寸日本の 17 港，図-3 に示寸日本以外 の東・東南・南アジア 23 港，図-4 に示寸その他の地域 10 港の，合計 50 港を対象（すなわち， $|P|=50$ ） とする. ただし，アジア以外の 10 港は，地域代表港として便宜 的に設定するものであり, 対象となる港湾の個別事情
表-2 本モデルの外生変数一覧

\begin{tabular}{|c|c|c|c|}
\hline 変数 & 内容 & 初出 & $\begin{array}{c}\text { 本章の } \\
\text { 記述 }\end{array}$ \\
\hline$V,|V|$ & リンクの集合と総数 & 式(1) & $\left(\begin{array}{c}3 \text { 章 } \\
(2) \sim(7)\end{array}\right)$ \\
\hline$A$ & 港湾の組み合わせ (ODペア)の集合 & 式(2) & $(1)$ \\
\hline$P$ & 港湾の集合 & 式(5) & $(1)$ \\
\hline$G,|G|$ & 船社の集合と総数 & 式(1) & (2) \\
\hline$W$ & 船舶サイズの集合 & 式(5) & $(2)$ \\
\hline $\operatorname{cap}_{w}$ & 船舶サイズwのキャパシティ & 式(5) & (2) \\
\hline$l_{i j}$ & 港湾 $i j$ 間の距離 & 式(5) & $(2)$ \\
\hline$l f_{v g}$ & リンク $v$, 船社 $g$ のロードファクター & 式(5) & (3) \\
\hline$v l_{w}$ & 船舶サイズ $w$ の船速 & 式(5) & (3) \\
\hline$C C R_{w g}$ & $\begin{array}{l}\text { 船舶サイズ } w, \text { 船社 } g \text { の単位時間あたり } \\
\text { 航行時費用 } \\
\end{array}$ & 式(5) & (3) \\
\hline$C A D_{i w}$ & 港湾 $i$, 船舶サイズ $w$ の入出港費用 & 式(6) & (3) \\
\hline$C P A_{w g}$ & $\begin{array}{l}\text { 船舶サイズ } w, \text { 船社 } g \text { の単位時間あたり } \\
\text { 停泊時費用 }\end{array}$ & 式(6) & (3) \\
\hline$C T E_{i}$ & 港湾 $i$ の単位時間あたりターミナル費用 & 式(17) & (3) \\
\hline $\mathrm{CHA}_{i}$ & $\begin{array}{l}\text { 港湾 } i \text { における搬出·搬入貨物の1 TEU } \\
\text { あたり荷役費用 }\end{array}$ & 式(23) & (3) \\
\hline$\gamma_{1}, \gamma_{2}$ & 入港待ち時間関数に関するパラメータ & 式(8) & (4) \\
\hline$N B_{i u}$ & 港湾 $i$, バースカテゴリuのバース数 & 式(8) & $(4)$ \\
\hline$T_{A R} R_{i w}$ & $\begin{array}{l}\text { 港湾 } i \text { における船舶サイズ } w \text { の港時 } \\
\text { に最低限必要な寺間 }\end{array}$ & 式(10) & (4) \\
\hline $\operatorname{prod}_{i}$ & 港湾 $i$ における1クレーンあたりの荷役効率 & 式(10) & (4) \\
\hline$N C_{i w}$ & $\begin{array}{l}\text { 港湾 } i \text { における船舶サイズ } w \text { の荷役時 } \\
\text { 使用クレーン数 }\end{array}$ & 式(10) & (4) \\
\hline$T D E_{i w}$ & $\begin{array}{l}\text { 港湾 } i \text { における船舶サイズ } w \text { の出港時に } \\
\text { 最低限必要な時間 }\end{array}$ & 式(18) & (4) \\
\hline$T T R_{i}$ & 港湾 $i$ における積替作業時間 & 式(23) & (4) \\
\hline$\left\{x_{v g}^{(0)}\right\}$ & 初期リンクフロー & $\begin{array}{c}\text { 3章 } \\
(8)\end{array}$ & (5) \\
\hline$\left\{X T_{i}^{(0)}\right\}$ & 港湾取扱量実績 & $\begin{array}{l}3 \text { 章 } \\
(8)\end{array}$ & (6) \\
\hline$q_{a g}$ & $\begin{array}{l}\text { 海上ODペア(航路) } a \text { における } \\
\text { 船社 } g \text { の貨物輸送需要 }\end{array}$ & 式(2) & (6) \\
\hline$v t_{g}$ & 金銭時間換算係数(船社の時間価值) & 式(5) & $\begin{array}{l}5 \text { 章で結 } \\
\text { 果を検証 }\end{array}$ \\
\hline
\end{tabular}

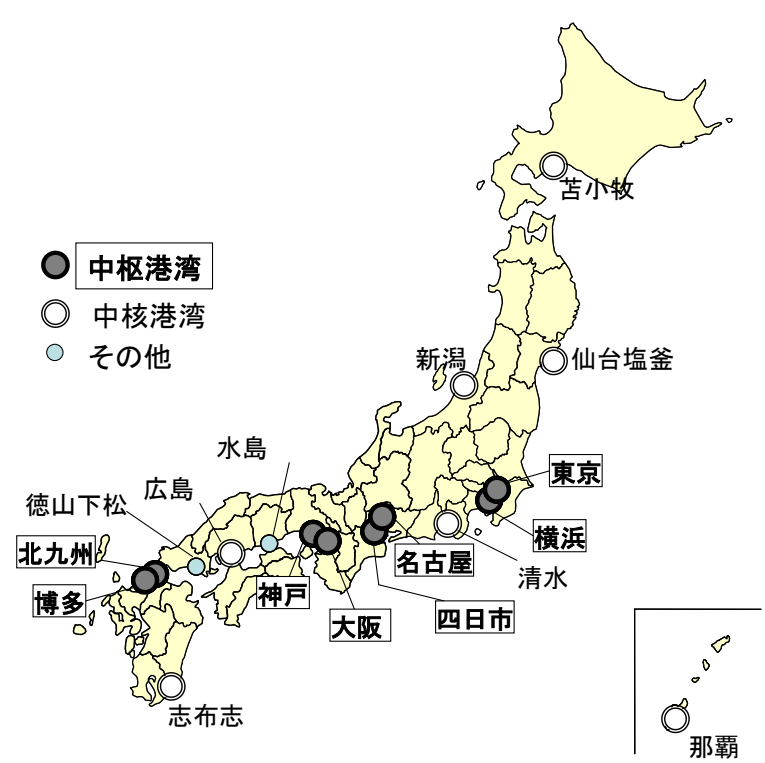

図-2 モデル対象港湾（日本）

（バース数など）はほとんど考慮しない. 


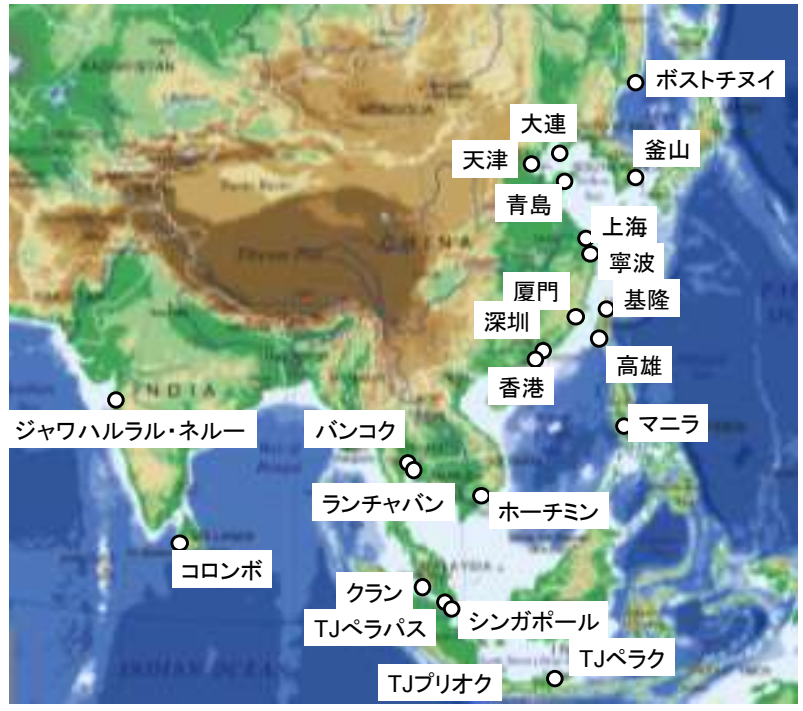

図-3 モデル対象港湾（日本以外の東・南アジア諸国）

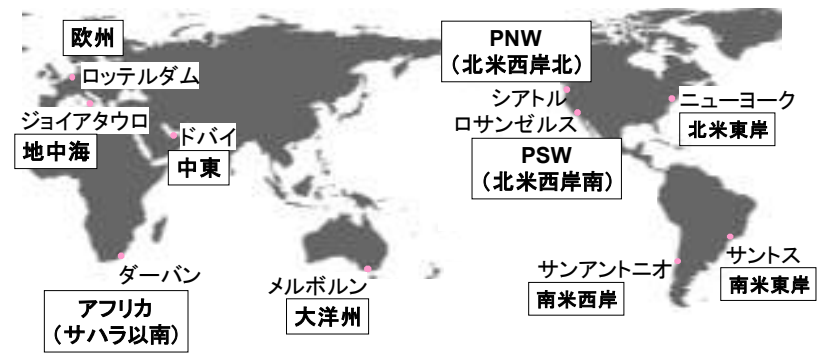

図-4 モデル対象港湾（その他地域）

\section{(2) 海上輸送ネットワーク}

対象港間（50港 $\times 49$ 港）の距離 $l_{i j}$ (海里）については, 距離表 ${ }^{19)}$ や Netpas Distance ${ }^{20)}$ 等を用いて整理した。 また, 本研究において考慮する船舶サイズとしては，表-3に 示すような 5 区分（すなわち，|W=5）とする. また， これらのサイズに対応するバース水深カテゴリと，その 関係についても表-3に示す.

計算対象とする船社については, 2003 年時点の国際 海上コンテナ輸送市場の状況を参考に，表-4 に示すよ うに，3つの単独船社，3つのアライアンス（船社グル

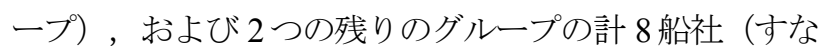
わち， $|G|=8 ）$ とした. 各グループの構成船社は，あた かも各グループが単独船社であるかのように，グループ 全体の輸送費用を最小化するよう協調的に行動するもの と仮定する.

\section{（3）輸送費用}

\section{a) 海上輸送費用}

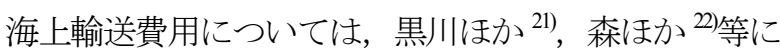
基づき，以下のように設定する，なおここでは，船社に よらず費用は同一と仮定する.
表-3コンテナ船サイズとバース水深カテゴリの設定

\begin{tabular}{c|c|c|c}
\multicolumn{5}{l}{ ○コンテナ船 } \\
\hline$w$ & $\begin{array}{c}\text { サイズ } \\
\text { (TEU) }\end{array}$ & $\begin{array}{c}\text { 平均サイ } \\
\text { ズcap } \\
\text { (TEU) }\end{array}$ & $\begin{array}{c}\text { 入港可能な } \\
\text { カテゴリ }\end{array}$ \\
\hline 1 & -1000 & 500 & $1-5$ すべて \\
\hline 2 & $1000-2500$ & 1750 & $2,3,4,5$ \\
\hline 3 & $2500-4000$ & 3250 & $3,4,5$ \\
\hline 4 & $4000-6000$ & 5000 & 4,5 \\
\hline 5 & $6000-$ & 8000 & 5 \\
\hline
\end{tabular}

\begin{tabular}{l|l}
\multicolumn{2}{c}{$\bigcirc$ バース } \\
\hline$u$ & 水深 $(\mathrm{m})$ \\
\hline 1 & 11.0 以下 \\
\hline 2 & $11.0-13.0$ \\
\hline 3 & $13.0-14.0$ \\
\hline 4 & $14.0-15.0$ \\
\hline 5 & 15.0 以上 \\
\hline
\end{tabular}

表-4 船社グループの設定

\begin{tabular}{c|c|c}
\hline グル & アライアンス名 & 主な構成船社 \\
\hline A & 単独 & Maersk \\
\hline B & 単独 & Evergreen, LT \\
\hline C & 単独 & MSC \\
\hline D & Grand Alliance & MOL, APL, Hyundai, NOL \\
\hline E & New World & $\begin{array}{c}\text { HAPAG-LLOYD, MISC, } \\
\text { NYK, OOCL, P\&O }\end{array}$ \\
\hline F & CKYH & COSCO, KL, Yang Ming, Hanjing \\
\hline G & $\begin{array}{c}\text { (その他 } \\
\text { アジア系) }\end{array}$ & $\begin{array}{c}\text { Cho Yang, CSAV, Heung-A, Namsung, } \\
\text { UASC, Sinotrans, Wan Hai }\end{array}$ \\
\hline H & $\begin{array}{c}\text { (その他 } \\
\text { アジア以外系) }\end{array}$ & CMA-CGM, PIL, ZIM, Wilhelmsen \\
\hline \multicolumn{3}{|c}{} \\
\hline
\end{tabular}

航行時運航費用 $C C R_{w}$ は, 変動費用である運航時燃料 費 $C C F_{w}$ （円/時）と，固定費用である船費 $C S P_{w}$ （円/ 時）にわけられる。

$$
\begin{gathered}
C C R_{w}=C C F_{w}+C S P_{w} \\
C C F_{w}=c 1 \cdot c 2 \cdot\left(c 3 \cdot c a p_{w}\right)^{\frac{2}{3}} \cdot v l_{w}{ }^{3}
\end{gathered}
$$$$
C S P_{w}=\left(c 4_{w}+c 5_{w}+c 6_{w}+c 7+c 8+c 9+c 10_{w}+c 11_{w}\right)
$$$$
*(1+r e) / D / 24
$$

変数 $c 1 \sim c 11, r e, D$ の説明，および本研究における設定值 は，表-5 に示寸通りである．また，サイズ別の船速 $v l_{w}$ （ノット）については，実際のコンテナ船のデータに基 づき推計した，以下のような近似式を用いる.

$$
v l_{w}=5.836 \cdot \operatorname{cap}_{w}^{0.167}
$$

停泊時運航費用 $C P A_{w}$ についても，航行時運航費用と 同様に，変動費用である停泊時燃料費 $C P F_{w}$ (円時）と, 固定費用である船費にわけられる，このうち，船費につ いては，航行時運航費用における船費と一致する.

$$
\begin{gathered}
C P A_{w}=C P F_{w}+C S P_{w} \\
C P F_{w}=0.17 \cdot\left(\mathrm{PS}_{\mathrm{w}} \cdot 0.09\right) \cdot 0.98
\end{gathered}
$$

ここで，PS は補機出力であり，

$$
\mathrm{PS}_{\mathrm{w}}=1.2 \cdot G T_{w}^{0.6} \cdot 2
$$

と表される。

以上より算定される，コンテナ船舶サイズごとの輸送 
表-5 海上輸送費用式(25)-(27)における变数の設定值 ${ }^{21), 22)}$

\begin{tabular}{|c|c|c|c|}
\hline 変数 & 説明 & 単位 & $\begin{array}{c}\text { 設定值 } \\
\end{array}$ \\
\hline$c 1$ & 燃料油単価 & 丹/t & 8925 (=85US\$/t*105円/US\$) \\
\hline$c 2$ & $\begin{array}{c}\text { 燃料消費量 } \\
\text { 係数 }\end{array}$ & - & $2.380 * 10^{-7}$ \\
\hline$c 3$ & $\begin{array}{l}\text { 排水量 } \\
\text { 換算係数 }\end{array}$ & $\begin{array}{c}\text { DWT/ } \\
\text { TEU } \\
\end{array}$ & 19.07 \\
\hline$c 4_{w}$ & $\begin{array}{c}\text { 船価 } \\
\text { (元利均等払) }\end{array}$ & 円/年 & $\begin{array}{c}\text { 総額: } \\
\left\{-6.966 * \ln \left(G T_{w}\right)+89.36\right\} * G T_{w} * 10^{4} \\
\left(こ こ て ゙ G T_{w}=\left(\text { cap }_{w}+15.13\right) / 0.0680\right) \\
\text { 而用年数14年, 年率 } 4.5 \% \text { 複利 } \\
\text { 計算により年間定期支払額を算出 }\end{array}$ \\
\hline$c 5_{w}$ & 船員費 & 円/年 & $\begin{array}{c}\text { 船員数 } \times \text { 船員給与 } \times 12 \\
\text { 船員数: } 2.959 * \ln \left(G T_{w}\right)-8.477 \\
\text { 船員給与 }: 58.3 \text { 万円 } \\
(=185(\mathrm{US} \$ / \text { 日 }) * 105 * 30(\text { 日 })) \\
\end{array}$ \\
\hline$c 6_{w}$ & 船用品費 & 円/年 & $624.7 * G T_{w}+2108$ \\
\hline$c 7$ & 修縊費 & 円/年 & $\begin{array}{l}\text { 毎年, 船価総額の } 2 \% \\
\end{array}$ \\
\hline$c 8$ & 船舶保険費 & 円/年 & 毎年, 船価総額の $0.3 \%$ \\
\hline$c 9$ & 固定資産税 & 円/年 & $\begin{array}{c}\text { 船価総額*1.1/而用年数/2 } \\
\text { *税率 }(1.4 \%)\end{array}$ \\
\hline$c 10_{w}$ & 雑費 & 円/年 & $648.6^{*} G T_{w}-1574$ \\
\hline$c 11_{w}$ & 投滑油費 & 円/年 & $\begin{array}{c}\text { 必要燃料油 }(\mathrm{t} / \text { 時 }) * 1.0 \% * 24 \\
* D * \text { 单価 }(20 \text { 万円 }) \\
\text { 必要燃料油: } c 2 *\left(c 3 * c a p_{w}\right)^{2 / 3} * v l_{w}{ }^{3}\end{array}$ \\
\hline re & 営業経費率 & - & $9.0 \%$ \\
\hline$D$ & 年間稼働日数 & 日/年 & 350 \\
\hline
\end{tabular}

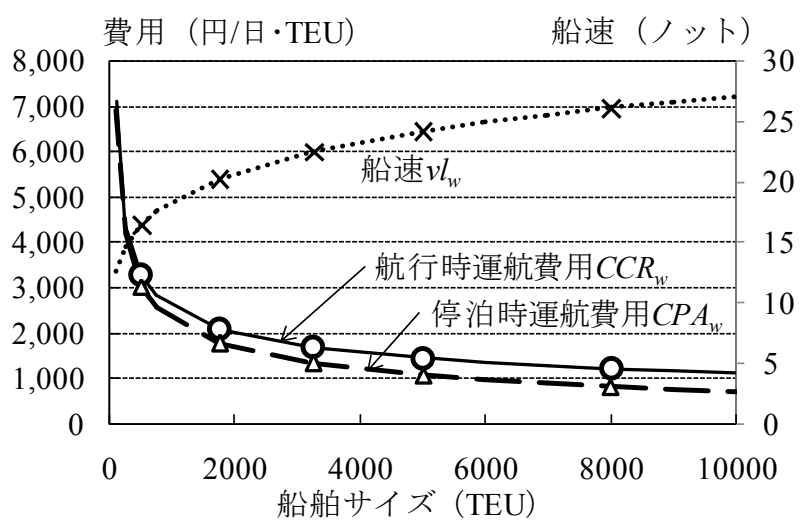

*運航費用はロードファクターを $80 \%$ と仮定したときの值

図-5 本モデルで設定した $1 \mathrm{TEU}$ あたり海上輸送費用および 船速と船舶サイズの関係

費用および船速を，図-5に示す．図より，船舶が大型 化するにつれて，1 TEU あたりの輸送費用は低減するも のの，大型化に伴い，低減の度合いは緩やかになること がわかる. また, 船舶が大型化するにつれて, 船速も増 加する.

さらに，ロードファクター $f_{\text {ixg }}$ については，実績が不 明であるため一律に同じ値を与えることも考えられるが, ここでは，それよりも現実的な仮定として，航走リンク コストの和が最小となるようにリンク別に決定されるも のとする（ただし, $0.1 \leq l f_{i j w g} \leq 0.9$ とする）．詳細につ いては，付録Bを参照されたい.

\section{b）港湾費用}

港湾費用については，前章で述べたとおり，1 TEU あ たりの費用として定義される荷役費 $C H A_{i} ， 1$ 隻あたりの 費用として船舶サイズ別に定義される入出港費 $C A D_{i w}$ 1 ターミナルあたりの費用として定義されるターミナル 費 $C T R_{i}$ の 3 種類にわけられる。 これらの入力值につい ては，各種資料を参考に，表-6 の通り設定した。ここ で，1 TEU あたりの費用に換算すると特にウェイトの大 きい荷役費用 $C H A_{i}$ については, ターミナル費用 $C T R_{i}$ と の合計が，世界銀行の Doing Business データベース ${ }^{23} に$ おける Trading Across Borders - Ports and terminal handling に示 される，国別の港湾費用と一致するように設定した.

\section{（4）輸送時間}

海上輸送時間を算出するための変数については, 前節 までですべて説明されている.

港湾内の所要時間のうち, 船舶の入出港混杂隹待ち時間 の算出に必要な, 各港湾における水深カテゴリ別のバー ス数 $N B_{\dot{u} \text { }}$ については, Containerisation International Yearbook $^{24)}$ や各港 HP などを参考に，表-6 に示すとおり設定 した. なお，アジア地域以外の港湾については，地域代 表港としての仮想的な設定であることから，入出港フロ 一に依存する待ち時間を実質的にゼロとするための，便 宜的な想定となっている.

また，積替作業時間 $T T R_{i}$ については，個別港湾につ いての情報が少ないことから，港湾の規模や発展段階， トランシップ貨物の比率 (トランシップ貨物を重視した オペレーションを行っているかどうかの代理指標とみな す）等に基づき，表-6に示す值を仮想的に設定した.

さらに, 各港湾における, 入港時および出港時に最低 限必要な時間 $T A R_{i w}, T D E_{i w}$ (ここでは船舶サイズによら ず一定と仮定する），1クレーンあたりの荷役効率 prod $_{i}$, 1 バースあたりクレーン数 $N C_{i w}$ についても, データが少 ないため，各港共通に $T A R_{i v}=T D E_{i w}=1$ (時）， $\operatorname{prod}_{i}=45$ （TEU/時）， $N C_{i w}=w+1$ とした。 また，船舶の混雑 (待ち時間) 関数に関するパラメータ $\gamma_{1}, \gamma_{2}$ は, 筆者ら によるこれまでの計算結果 ${ }^{11)}$, 12)に基づき， $\gamma_{1}=120.0$, $\gamma_{2}=5.0$ とした. 図一 6 に, 設定した混雑関数を示寸. 図 より，1 バースあたりの 1 時間あたり入出港船舶数と 1 隻あたり荷役時間の積が 0.3 を超えるあたりから, 混雑 による船舶の期待入出港待ち時間が，急激に増加するこ とがわかる。

\section{（5）初期輸送フロー（船社別港湾間輸送実績）}

船舶サイズ別船社別の港湾間輸送実績は，MDS Transmodal 社の航路別船社別の寄港実績データ ${ }^{25}$ から明 らかとなる, 寄港地順・頻度・船舶サイズを整理するこ とで, 船舶サイズ別船社別の港湾間年間就航船腹量 
表-6 本研究で設定した港湾諸元

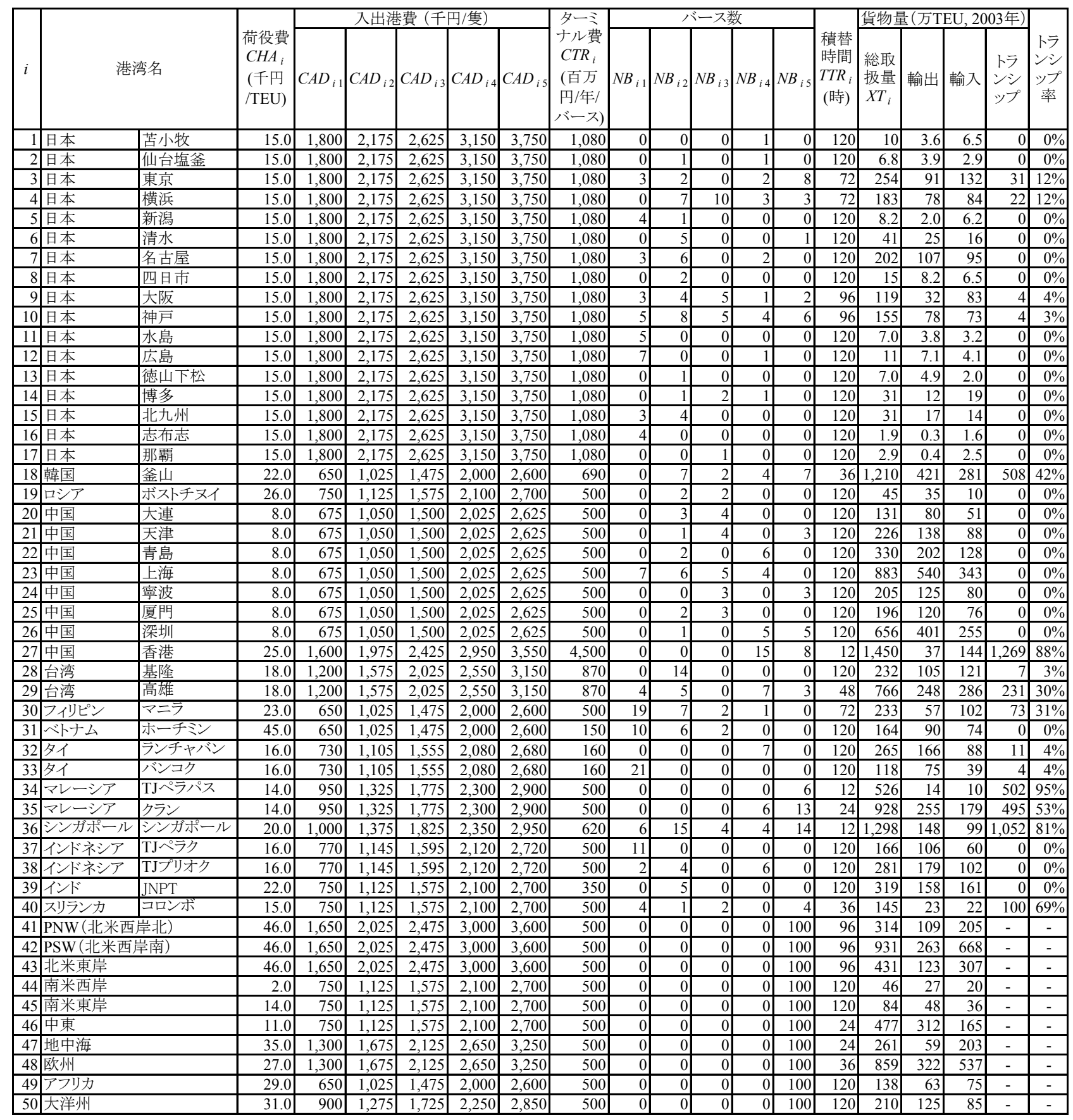

船舶の期待混雑待ち時間

$T W A_{i w}$ および $T W D_{i w}$ (時)

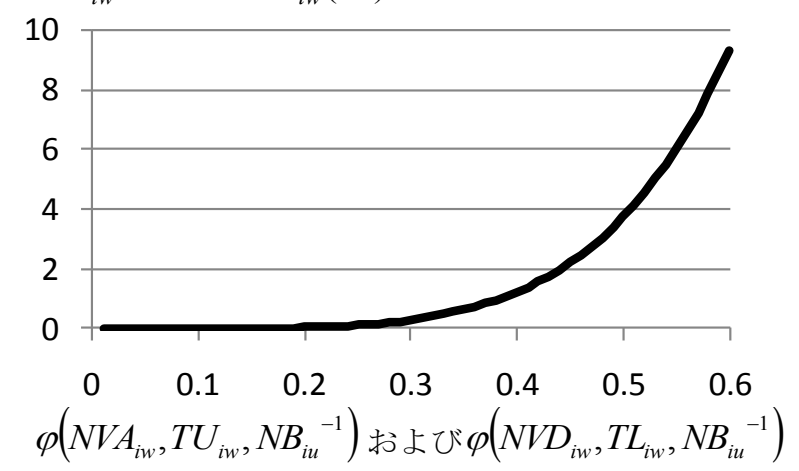

（TEU ベース）を求め，これに消席率を乗じることで 得られる. ここで，消席率の実績值 (初期值) について は，詳細データが得られず，付録 B に示した方法も適 用できないため，全区間につき 0.8 と想定した. このよ うにして得られたフローを，4 種類の航走リンクフロー に分割する．ここでは，簡便な方法として，航走リンク フロー $X C_{m g}$ と港湾取扱量 $X T_{i}$ に関する恒等式

$$
\sum_{g \in G} \sum_{v \in V}\left(X C_{2 v g}+X C_{3 v g}+2 \cdot X C_{4 v g}\right) \equiv \sum_{i \in P} X T_{i}
$$

が成り立つよう, 港湾取扱量の実績に基づき，すべての リンク vにおいて, $X C_{1 v g}: X C_{2 v g}: X C_{3 v g}: X C_{4 v g}=3: 3: 3: 1$ と

図-6 本研究で設定した船舶の入出港時における混雑関数 
仮定した. この仮定は，2 港間をダイレクトに結ぶ直航 航路と多数の港に寄港するループ型の航路の輸送比率が 1:3 で，かつループ型航路の平均寄港数が 4 (発着港を 含む)であることを意味しており，この種の実績に関す る統計が存在しないため, 正確な比較は行えないものの, 上述の航路別船社別寄港実績データ ${ }^{29}$ や船社インタビュ 一の結果等から推測する限り，おおむね実際の国際海上 コンテナ輸送に沿った設定と判断できる.

\section{（6）船社別港湾間国際海上コンテナ貨物輸送需要（船 社別港湾間 OD）および港湾取扱量実績}

国際海上コンテナ貨物の世界的な ODデータは存在し ないため，独自に作成するものとする．基本的な方針と しては，2 国間貿易額データを出発点に，輸送機関分担 率や単価, コンテナ化率，港湾別や船社別の取扱量シェ アを乗じることによって推計する．また，これを集計す ることによって, 各港のコンテナ取扱量実績を得る.

\section{a) 2国間輸送需要}

出発点となる 2 国間貿易額は, 今後の経済政策シミュ レーションや将来予測実施との整合性を考慮し, GTAP (Global Trade Analysis Project) データベース ${ }^{29)}$ (ver 6.0, 2001 年ベース）を日本 8 地域・中国 7 地域に分割した ${ }^{27}$, 全世界 48 ケ国・地域，10品目（うち貿易財 5 品目）の 貿易額データを基本に, Global Trade Navigatorデータ ${ }^{28)}$ と の整合や年次補正を考慮した，2003 年ベースの品目別 2 国間貿易額（31 力国・地域，5貿易財品目）を作成する これについて, Global Trade Navigatorデータより得られる 品目別輸出入国別の, 海上輸送分担率, 海上輸送貨物の トン・金額換算係数, 海上コンテナ分担率, TEU・トン 換算係数を順に乗じることにより，2 国間国際海上コン テナ貨物輸送量データ（2003 年, TEU ベース）を作成 する. なお, 本研究のデータベースは, 原則として FOB 価格で構築するものとし, 輸出国側と輸入国側で データが一致しない場合には，輸出国側のデータを採用 するものとする.

\section{b) 港湾間輸送需要}

港湾間貨物輸送需要の実績データは存在しない，そこ で本研究では，a)で得られた 2 国間国際海上コンテナ貨 物輸送量をベースに，以下の手順で，港湾間貨物輸送需 要を推計する.

(i) 日本発着貨物については, コンテナ貨物流動調査 ${ }^{18)}$ により, 自国港湾別相手国別の輸出入コンテナ貨物 量が得られるため, このシェアを用いて, 日本 8 地 域別の発着相手国別コンテナ貨物量を, 港湾別相手 国別貨物量に比例配分する.

(ii) アジア各港発着貨物については, Containerisation International Yearbook ${ }^{24)}$ 等より得られる, 自国のコンテナ貨 物取扱量（ただしトランシップ貨物量は除く）に占
める自港のシェアを用いて, 2 国間国際海上コンテ ナ貨物輸送量を比例配分することで, 自国港湾別相 手国別の輸出入コンテナ貨物量を推計する. なお, 相手国側も日本を除くアジア各港である場合は，相 手国側についても同様の操作を行い, 自国港湾別相 手国港湾別の輸出入コンテナ貨物量を得る.

(iii) アジア地域外発着貨物については, 当該地域に含ま れるすべての国の貨物を集計し，相手国港湾別の貨 物量を作成する，なお，アジア地域外同士を発着す る貨物は，本モデルの計算対象外としゼロとする.

また, 北米（本研究ではパナマ以北を指す）につい ては，各国を最大で PNW（北米西岸北），PSW（北 米西岸南) , 北米東岸の 3 地域に分割した貨物量デ 一タを作成する必要があるため, 各国の主要港の取 扱量を参考にして, 上記 3 地域のシェアを各国別に 算出し，それを集約することとする.

\section{c) 港湾取扱量実績}

b)の港湾間輸送需要を港湾別に集計すれば，各港湾の 輸出・輸入貨物量実績が得られる. これに対し, 各港の 統計等より別途推計した各港のトランシップ貨物率を考 慮することで, 総取扱貨物量（=輸出入貨物量／ (1 - トランシップ貨物率) ) が得られる.このように 設定した港湾取扱量実績について，表-6 に示寸。ここ で，表に示された取扱量が，文献 ${ }^{24}$ 等に示された実際の 各港の 2003 年における実入りコンテナ取扱貨物量と多 少異なるのは, (i)地域間 OD 貨物量推計時点での誤差, (ii)モデルで考慮されていない国々との輸出入貨物を考 慮していないことに起因する誤差, (iii)モデルで考慮さ れている国については，逆に，モデルに含まれない当該 国の中小港湾で取り扱われた貨物も，モデル対象港湾で 取り扱われると仮定されていることに起因する誤差が存 在するためである.

\section{d) 船社別港湾間輸送需要}

c)の各港湾輸出入港湾取扱貨物量（トランシップ貨物 量は除く）を，(5)で得た船社別入出港フローで比例配 分した, 船社別港湾別輸出・輸入貨物取扱量をコントロ ールトータルとし，b)で作成した全船社合計の港湾間貨 物輸送需要を初期值として, フレーター法により, 船社 別港湾間貨物輸送需要を推計する.

\section{5. モデルパフォーマンスの検証}

本章では，モデルの収束状況，費用やサイズの内訳， 取扱量の再現性確認といった計算結果の検証を行う。こ こで，前章冒頭で述べたように，モデルに含まれる変数 のうち金銭時間換算係数 $v t_{g}$ については, 実績に基づき 適切な值を設定することが困難なため, $v t_{g}=10^{0}, 10^{1}, 10^{2}$, 
$10^{3}, 10^{4}, 10^{5}$ (円/時/TEU) としたときの結果を比較する.

\section{(1) モデルの収束}

3.(8)に示した計算は，予め収束が保証されるものでは ないため，計算結果より収束状況を確認する。図-7に, 収束状況の例（ $v t_{g}=10^{0}, 10^{3}, 10^{5}$ の 3 ケース）を示す. 図 に示さなかったケースを含め，5～10 回程度の繰り返し 計算で, 誤差 $\Delta_{g}^{(n)}$ がおおむね $10^{-3} \sim 10^{4}$ 以下となった.

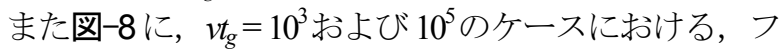
ロー $\left\{x_{v g}^{(n)}\right\}$ の 1 期前の計算結果 $\left\{x_{v g}^{(n-1)}\right\}$ との比較を示す. 収束の遅い $v t_{g}=10^{5}$ のケースにおいても, ある程度繰り 返し計算を行った場合 $(n=10$, 右図 $)$ には, フローの 変化が十分小さくなっている. 以上より, 実用的な範囲 において，本モデルの計算は十分収束すると考えられる. なお，以降の計算では，収束判定基準 $\varepsilon_{C}=10^{4}$, 計算打 ち切り回数 $n_{\max }=10$ とする.

\section{（2）輸送費用と海上輸送フローの内訳}

図-9に，本モデルより計算された総輸送費用（全船社 グループ合計）の，項目別内訳を示す．ここでは，図-9 下表に示すとおり，2種類の金銭的費用と4種類の時間費 用の内訳を示している. 図より，vtg 以下のとき，金銭的費用が大半を占め，vt きいときは，時間費用が大半を占めることがわかる。ま た，金銭的費用の中では，港湾費用の占める割合が大き

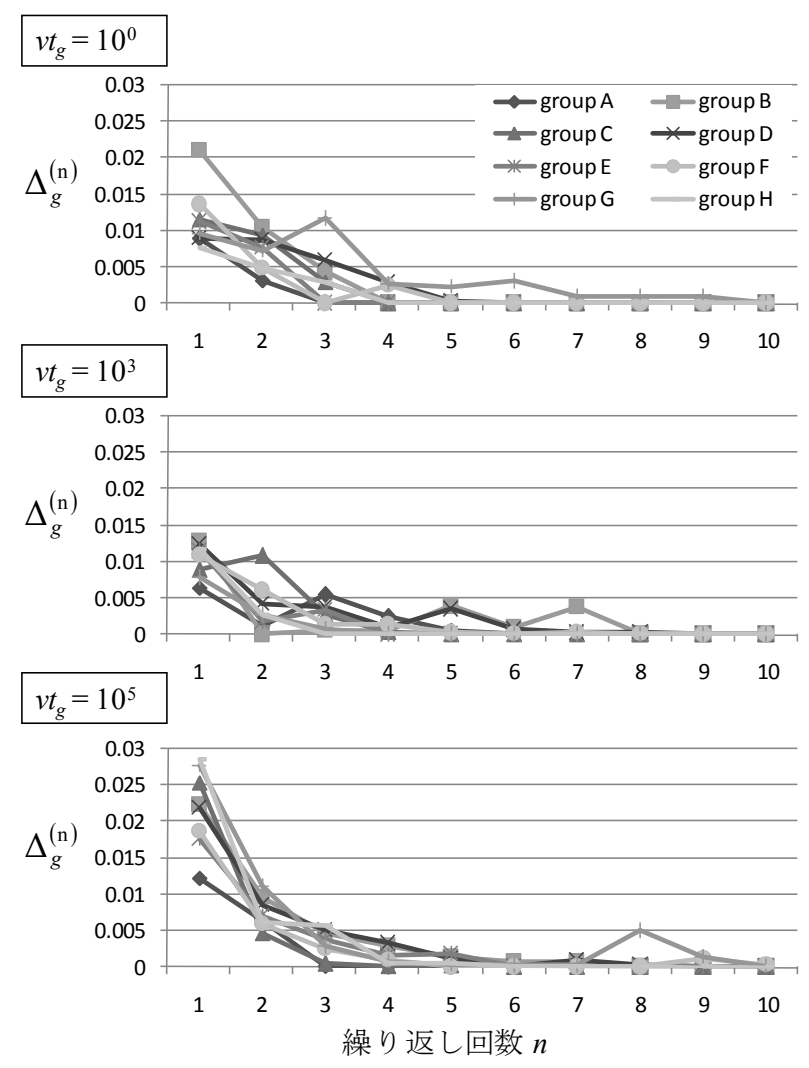

図-7 計算の収束状況

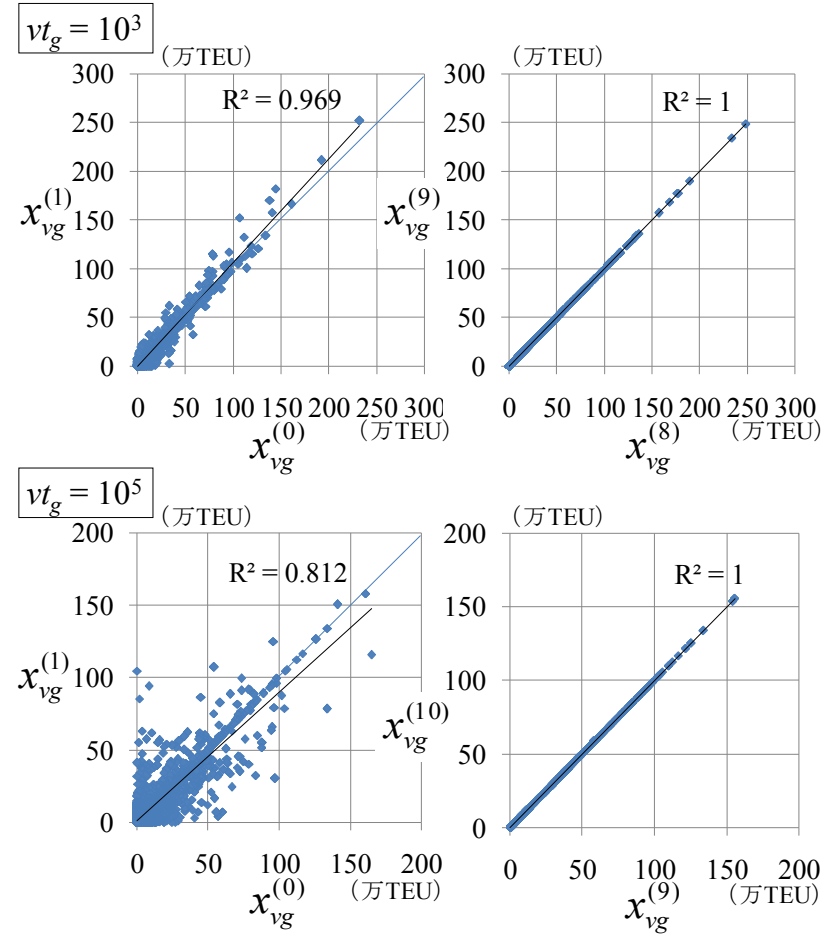

図-8 繰り返し計算回数とフローの変化

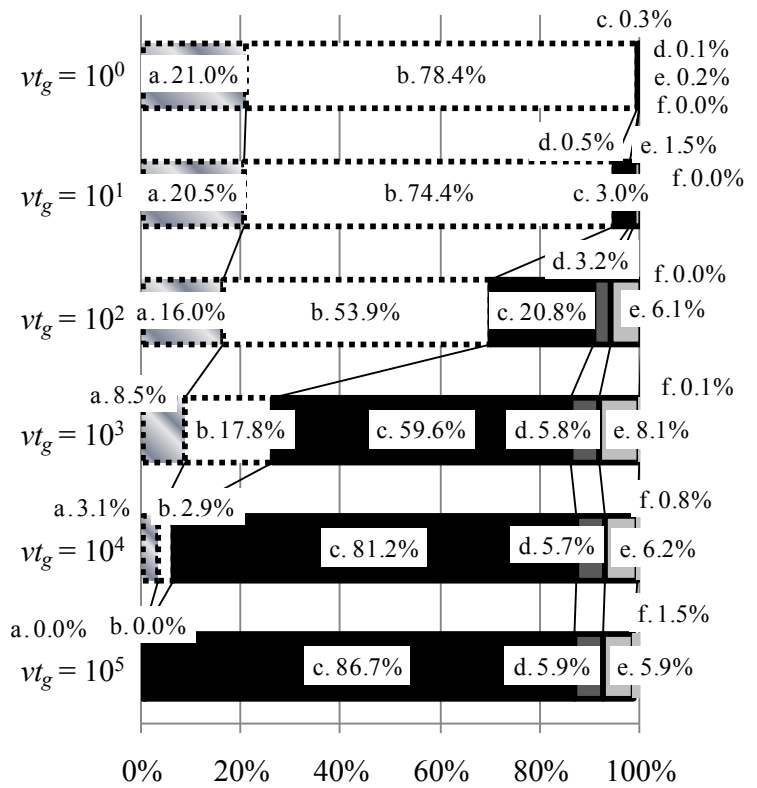

\begin{tabular}{|c|c|c|c|}
\hline \multicolumn{3}{|r|}{ 項目 } & 内容 \\
\hline \multirow[t]{2}{*}{$\begin{array}{l}\text { 金銭的 } \\
\text { 費用 }\end{array}$} & $\mathrm{a}$ & $\begin{array}{l}\text { 船舶費用 } \\
\text { (航行時および停泊時) }\end{array}$ & $\begin{array}{l}\text { 式(5)に含まれるCCRに関する } \\
\text { 項, 式(6), (12), (18), (20), (22)に } \\
\text { 含まれるCPAに関する項 }\end{array}$ \\
\hline & $\mathrm{b}$ & 港湾費用 & a以外の金銭的費用 \\
\hline \multirow{4}{*}{$\begin{array}{l}\text { 時間 } \\
\text { 費用 }\end{array}$} & $\mathrm{c}$ & 海上輸送時間費用 & $\begin{array}{l}\text { 式(5)に含まれる航行時間費用に } \\
\text { 関する項 }\end{array}$ \\
\hline & $d$ & 港湾内滞在時間費用 & $\begin{array}{l}\mathrm{c}, \mathrm{e}, \mathrm{f} \text { 以外の金銭時間換算係数 } \\
\text { を含む費用 }\end{array}$ \\
\hline & e & $\begin{array}{l}\text { 運航間隔に比例する貨物 } \\
\text { の期待待ち時間費用 }\end{array}$ & $\begin{array}{l}\text { 式(5)に含まれる待ち時間に関す } \\
\text { る費用 }\end{array}$ \\
\hline & $\mathrm{f}$ & \begin{tabular}{|l} 
港湾混雑による船舶の \\
入出港待ち時間費用
\end{tabular} & $\begin{array}{l}\text { 式(6)および(12)の金銭時間換算 } \\
\text { 係数を含む費用 }\end{array}$ \\
\hline
\end{tabular}

図-9 総輸送費用の内訳と金銭時間換算係数の違いによる相違 
く，時間費用の中では，海上輸送時間に関する費用の占 める割合が大きい.

図-10に，全航走リンク・全船社グループ合計の，海 上輸送フロー ${ }^{3} の$ 船舶サイズ別シェアに関する, 実績值 と各推計值の比較を示寸. 図より, vtgが非常に小さい場 合 $\left(v t_{g}=10^{\circ}\right)$ には，図-9に示されたように，運航間隔 に比例する貨物の期待待ち時間費用を含めた時間費用が ほとんど影響しないため，1 TEUあたりの船舶・港湾費 用が安い大型船が，より利用される結果となっている.

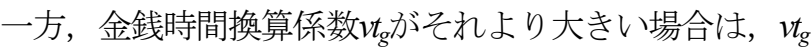
が非常に大きくなるとサイズ2およびサイズ5のシェアが 若干増加し, サイズ4のシェアが若干減少する傾向にあ るものの，おおむね神績值と同程度のシェアとなってい る. この理由として, $v t_{g}$ が大きい場合, 運航間隔に比例 する貨物の期待待ち時間を削減するため, 小型化によっ て高頻度サービスを提供するという誘因と，海上輸送時 間を短縮するため，よりスピードの速い大型船を利用す るという誘因が，ともに働くことが考えられる 4 .

また図-11に，4 種類の航走リンク別のフロー内訳を 示す．図より，vtg゙ $10^{3}$ (円/時/TEU) 以下のときは，お おむ敉実績と同様のシェアとなる一方で，vtg がそれよ り大きい場合は，航走 I リンクのシェアが減少する。こ れは，寄港数を絞り込んで輸送時間を短縮する誘因が働 いているためと考えられる.

以上より, 特に $v t_{g} か ゙ ~ 10^{2} \sim 10^{3}$ (円/時/TEU) のとき, リンクフローのサイズ別や種類別の内訳が実績と同程度 となっており，本モデルにおいて，船社の船舶サイズ選 択や輸送パターン選択といった配船行動が，一定程度再 現できているものと考えられる.

\section{（3）各港のトランシップ取扱量}

図-12 は，主要港湾における，トランシップ貨物量の 実績值と推計值を示寸．なおここで，本モデルにおいて は陸上輸送を考慮していないため, トランシップ以外の 貨物（ローカル貨物）は，全港湾において所与である.

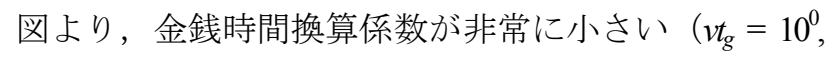

\footnotetext{
${ }^{3}$ 以下の分析では, アジア以外の港湾は地域代表港として位置付け られ，正確な評価を行うことが難しいため，アジアを発地または 着地とするフローに限定する。 このため，たとえば図-11 における 航走 II リンクと航走 III リンクのフロー合計をみても，実績值以外 は一致しない.

${ }^{4}$ なお，運航間隔については，金銭時間換算係数 $v t_{g}$ が大きい場 合，モデル内生化されている各リンクの消席率 $l l_{\text {jigg }}$ が減少する ことで，1 TEUあたりの船舶費用（1隻あたりの輸送個数に反比 例，式(5)第1項参照）を増加させてでも頻度を増加させ，待ち 時間を減らすといらメカニズムも，あわせて働いていると考え られる．実際に，全航路の平均消席率（フローの重み付き平

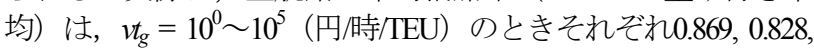
0.583, 0.247, 0.123, 0.101 となっており，vt无大゙きくなるほど，消 席率が減少している.
}

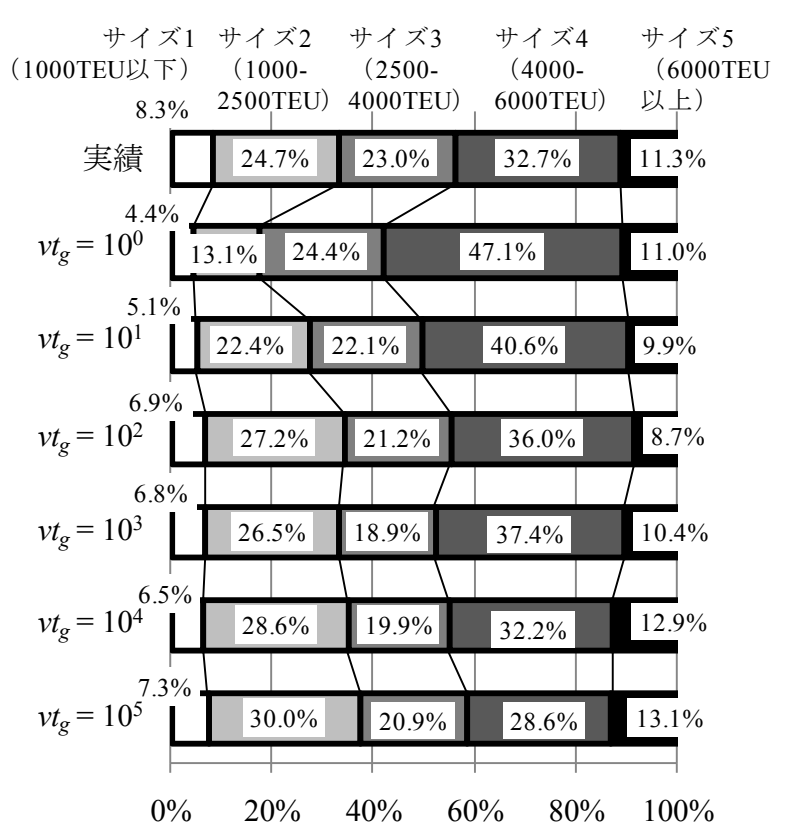

図-10 海上輸送フローの船舶サイズ別内訳

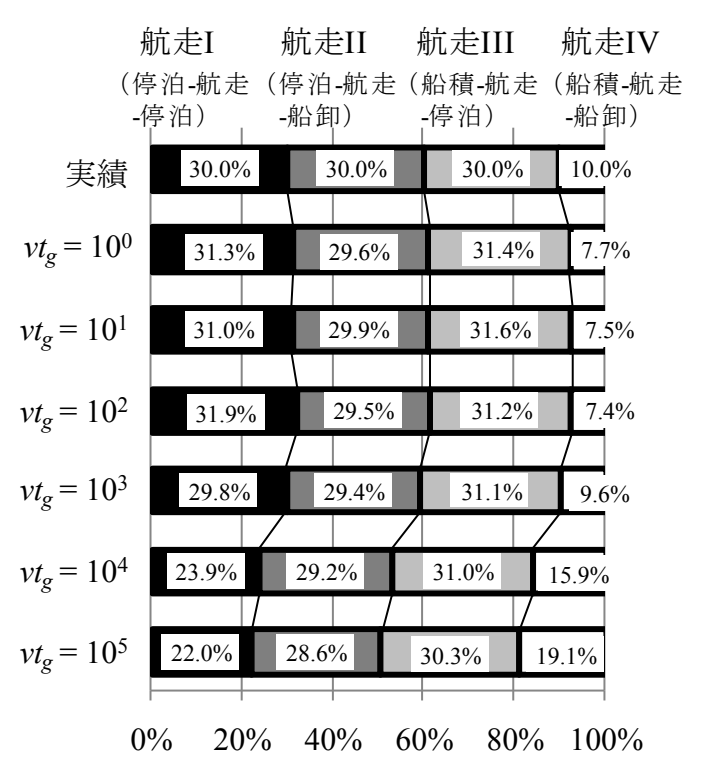

図-11 海上輸送フローのリンク種類別内訳

101) ときは，図-9 に示したように，港湾費用の全輸送 費用に占める割合が大きいため，全体的にトランシップ 貨物量が小さい. そのなかで，表-6に示されるように， 深圳をはじめとする中国本土諸港のように，周囲に比べ て荷役費 $C H_{i}$ やターミナル費 $C T_{i}$ がかなり小さい港湾や, ランチャバン・TJ プリオク港のように，周囲に大型船 の入港が不可能な港を伴う港湾においてのみ, トラン シップの取り扱いが観察される. 一方, 釜山・香港・シ ンガポール・コロンボといったハブ港湾や日本諸港にお いては，利用料金が相対的に高いことから，vtgが小さ いときは，トランシップ港として利用されないものの，

\footnotetext{
5それぞれバンコク，TJペラクが相当する.
} 
百万TEU

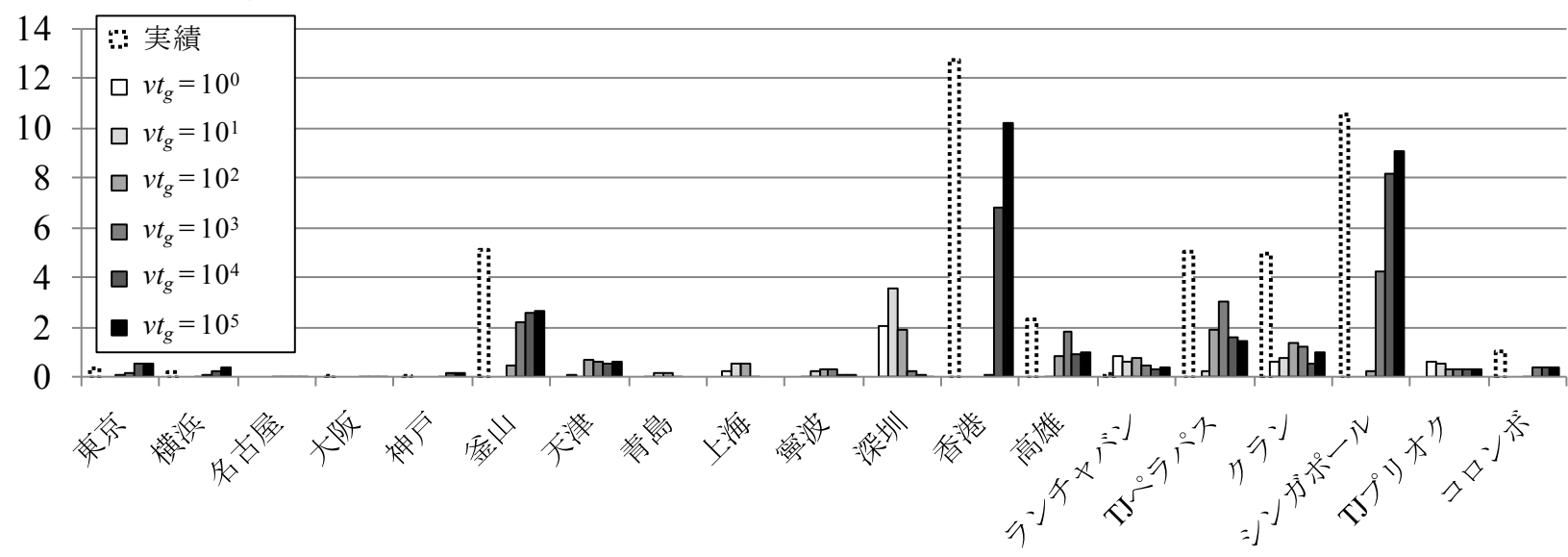

図-12 主要港湾におけるトランシップ貨物取扱量の再現性比較

$v t_{g}$ が十分大きく，輸送時間重視の傾向が強い場合には, ある程度の取扱量が推計されることがわかる．また，TJ ペラパス・クラン・高雄といった中間的な利用料金が設 定されている港湾では，トランシップの取り扱いについ ても中間的な結果となっており，あまりに $v t_{g}$ が小さい 場合の利用は多くないものの, 釜山・香港・シンガポー ル等に比べれば，vtg が比較的小さく金銭費用がより重 視される状況下 $\left(v t_{g}=10^{2} \sim 10^{3}\right)$ で，より多くのトラン シップ取扱量が観察される.

本モデルが，3.(8)で述べたように，リンクフロー実績 值を初期值とした収束計算を行っていることと併せて考 えれば，輸送時間重視の状況では，現状において船舶が 集中する港湾が，運航頻度の面から有利であることがう かがえる，言い換えると，現状においてトランシップ取 扱量の多い港湾は，現状において八ブ港であるという先 行者利益を有しており，比較的強気の利用料金を設定寸 ることが可能な一方で，新興港湾は，先行の港湾よりも 利用料金を低く設定することで貨物を奪う機会を狙って おり，vtgが小さく，金銭費用もある程度重視される状 況では，このような戦略が成功する可能性があることが 示唆される.

なお，図-12 において金銭時間換算係数 $v t_{g}$ が大きい場 合でも，釜山・香港・シンガポールをはじめとする，各 ハブ港におけるトランシップ貨物量の推計值が，実績に 比べ小さくなっている. この原因としては，(i)本研究に おいては, 主要港湾のみを対象としており, 周辺中小港 湾からフィーダー輸送される貨物が十分考慮されていな いこと, (ii)これらハブ港においては, 外航船社だけで なく, 荷主やフォワーダーにとっても国際貿易拠点の機 能を有しており, 本研究では想定していない「船社グル ープ間」の積み替えも考えられること，(iii)さらに香港 については，再輸出という特殊な貿易形態があり，これ
を十分考慮できていないと思われること崖，などがあげ られる。なお，(ii)であげた船社グループ間の積替につ

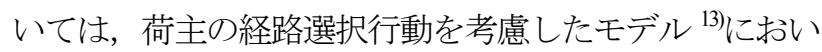
て，追加的に考慮することとする.

\section{6. モデルを用いた感度分析 〜規模の経済・不経済の影響〜}

本章では，本モデルにおいて定式化した海上輸送や港 湾における規模の経済・不経済が，モデルの出力結果に 及ぼす影響を，感度分析を行うことによって確認する. なお，本章における金銭時間換算係数は，中間的な結果 が得られる $v t_{g}=10^{3}$ (円/時/TEU) とする.

\section{(1) モデルにおける規模の経済の影響}

5.(1)で示したように，本モデルの計算が5〜10回程度 で収束することの一因として，モデル内で仮定された規 模の経済が，強く働いていることが考えられる．このこ とを確認するため, 3.で定式化したコス卜関数において 規模の経済（リンクフローの逆関数）が仮定されている, 式(5)（航走リンク），および式(20)，(22）(船卸・船積 リンク）に関し，パラメータや関数形を変化させたとき の影響をみる.

\footnotetext{
6 「再輸出貨物」は，香港特有の貿易形態であり，単なる転送貨物 のため性格上は限りなくトランシップに近いにもかかわらず，書 類上は輸出入に計上される. 世界貿易に関する統計データでは, 通常, 輸出入と定義されることが多いが，本研究ではトランシッ プ貨物として扱っている (図-12 に示される香港のトランシップ実 績のうち，約半数が再輸出貨物である）。ただし，書類上だけで も貨物の「囲い込み」をしていることから，実際には，純粋な卜 ランシップ貨物よりは, 積替港湾選択の流動性が若干低いと考え られる。
} 


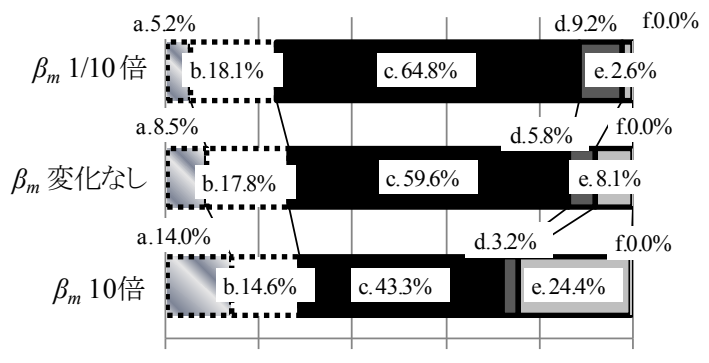

$\begin{array}{llllll}0 \% & 20 \% & 40 \% & 60 \% & 80 \% & 100 \%\end{array}$

図-13 運航間隔のウェイトに関するパラメータ $\beta_{k}$ による総輸 送費用内訳の差異（vt $t_{g}=10^{3}$, 費用項目の凡例は図-9を 参照)

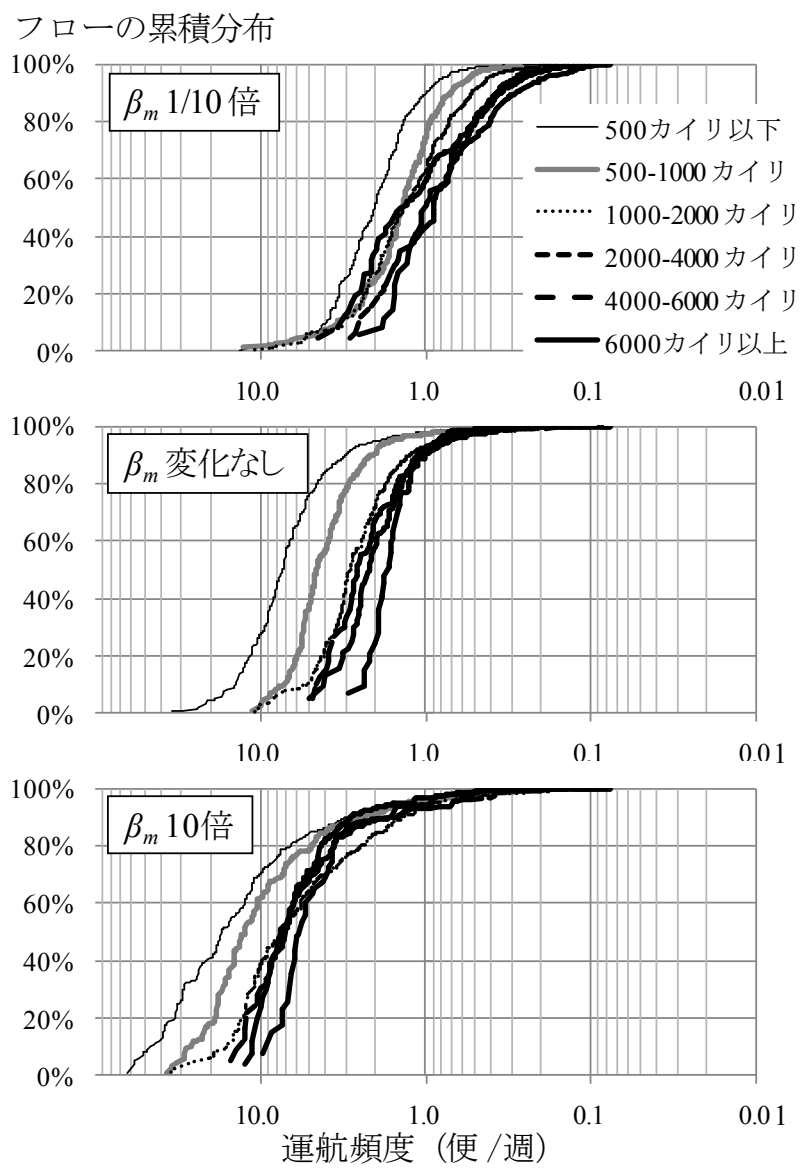

図-14 リンク距離帯別の運航頻度とフローの関係

\section{a) 運航間隔（貨物の期待待ち時間）に関する規模の経} 済

式(5)に含まれる，運航間隔のウェイトに関するパラ メータ $\beta_{m}$ を，一律に10倍および1/10倍としたときの結果 を比較する．図-13に， $\beta_{m}$ を変化させた際の，総輸送費 用の項目別内訳を示す．図より， $\beta_{m}$ を1/10倍したケース では，海上輸送時間費用の割合が大きくなり，逆に10倍 したケースでは，貨物の期待待ち時間に関する費用の割 合が大きくなるという妥当な結果が得られる.

それぞれのケースにおける，各海上リンクの頻度とフ

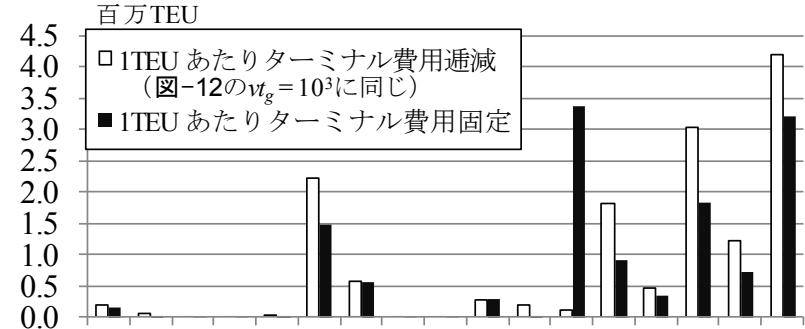

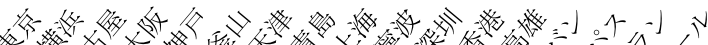

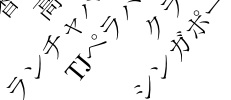

図-15 ターミナル費用の考慮方法による主要港トランシップ 貨物取扱量の推計值比較 $\left(v t_{g}=10^{3}\right)$

ローに関する累積分布（距離帯別のリンクフローを頻度 の大きいものから順に積み重ねたもの）を，図-14に示 す． $\beta_{m}$ を変化させる前のケース（図-14中段）をみれば, 6000カイリ以上のリンク（おおむね教アジア〜北米・欧州 間に相当）においては，週1～2便というサービスレベル のリンクが大半であり，また，リンク距離が短くなるに つれて，より高頻度のリンクが多い傾向にあることがわ かる．リンク距離が短くなるほど高頻度のリンクが多い のは，式(5)に示されるように，距離が短いと，航走リ ンクコストに占める貨物の期待待ち時間に関する項のウ エイトが高まり，規模の経済が強まって特定のリンクに フローが集中しやすくなるためと考えられる.

また，図-14中段と上・下段の結果を比較すれば， $\beta_{m}$ が1/10になり貨物の期待待ち時間のウェイトが下がると, 運航頻度も全体的に減少する一方で， $\beta_{m}$ が10倍になると， 運航頻度が増加する傾向にあることがわかる。この傾向 は，上述のように，頻度に関する規模の経済がより強く 発揮される短距離リンクで特に顕著であり， $\beta_{m}$ が10倍に なると, リンク距離による頻度の違いが大きくなる.

以上の結果はすべて，式(5)において定式化された運 航間隔に関する規模の経済が，想定された働きをしてい ることを示している.

\section{b) 港湾取扱量に関する規模の経済}

式(20), (22)においては，当該港湾の総取扱量 $X H_{i}$ が増加 するにつれ，1 TEUあたりターミナル費用が減少すると いう，規模の経済が仮定されている，比較のため，式 (20), (22)において $\left(\sum_{u} N B_{i u} \cdot C T_{i}\right) / X H_{i}$ で表されている1 TEUあたりターミナル費用を，港湾や取扱量によらず固 定值（10,000円/TEU） とした場合の，トランシップ取扱 量の推計值を, 図-15に示す，図より，港湾取扱量に関 する規模の経済を考慮せず，1 TEUあたりターミナル費 用を固定したケースでは，多くの主要港湾でトランシッ プ量が減少し，全港湾合計のトランシップ量も減少する 
（約8.3\%の減少）。例外は香港のように，表-6に示され る1バースあたりのターミナル費用 $C T_{i}$ が，ライバル港よ りも相対的に高く設定されている港湾に限られる.この ことから，1 TEUあたりターミナル費用が低減するとい う港湾取扱量に関する規模の経済も，本モデルの計算結 果に対して，想定された方向に働くことが確認できた.

\section{（2）モデルにおける規模の不経済と大水深化の影響}

(1)と逆に，式(6)，(12)（入港・出港リンク）のうち $T W A_{i w} Ｔ W D_{i w}$ に関寸る項，および式(20)，(22）(船卸・船 積リンク）のうちTUG $G_{\text {ivg }}, T L G_{\text {ing }}$ に関する項は, 規模の 不経済（リンクフローの増加に比例してコストが増加） が仮定されている．ただし，図-9に示される結果（前者 の $T W A_{i w}, T W D_{i w}$ に関する費用は図-9のf.，後者の $T U G_{i v g}$ $T L G_{\text {ivg }}$ に関する費用はd.に相当する）をみればわかるよ うに，特にf.船舶の入出港待ち時間に関する規模の不経 済の影響は，(1)で示した規模の経済と比べて，限定的 なものになると予想される.

そこで以下では，規模の不経済に関連する具体的な施 策を念頭に，感度分析的な検討を行い，想定される方向 への変化が得られるかについて検証する．なお，港湾の バース数に関する検討においては，バース数を増やさず に大水深化のみを行うケースについても，あわせて試算 を行う。

a) 港湾混雑に関する規模の不経済とバース増設の影響

多数の船舶が入出港寸ることによる混雑に伴う, 船舶 の待ち時間（式(6)のTWA るため, (i)日本の港湾の中で比較的混雑の激しい名古屋 港（平均待ち時間：0.079時間）, および (ii)世界の港湾 の中で混雑の激しい上海港（同0.45時間）について，既 存最大水深（両港ともにカテゴリ4）のバースが倍増

(それぞれ，2ないし4バース増設）したケースと，現状 值を比較する. このとき，両港の平均待ち時間は，それ ぞれ0.030時間，0.049時間に減少し，それぞれの港湾の

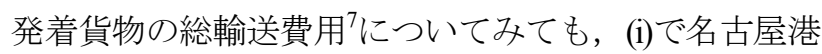
発着貨物の総輸送費用が $2.4 \%$ 減少し, (ii)で上海港発着貨 物の総費用が $0.26 \%$ 減少した. 一方, 図-16に示される各 港のトランシップ貨物量については, いずれのケースで もほとんど変化はみられない，以上より，バース増設に よる港湾混雑の緩和は，当該港における待ち時間と輸送 費用を減少させる一方で，(1)で検討した内容と比較す れば，世界の国際海上コンテナ輸送パターンに及ぼす影 響は限定的なものと考えられる.

7 ターミナル費用は, 式(20), (22)に示されるように，1 バースあたり の年間リース費用とバース総数の積として定義されているため, バース増設に伴う追加的な費用も，総輸送費用に含まれることと なる.

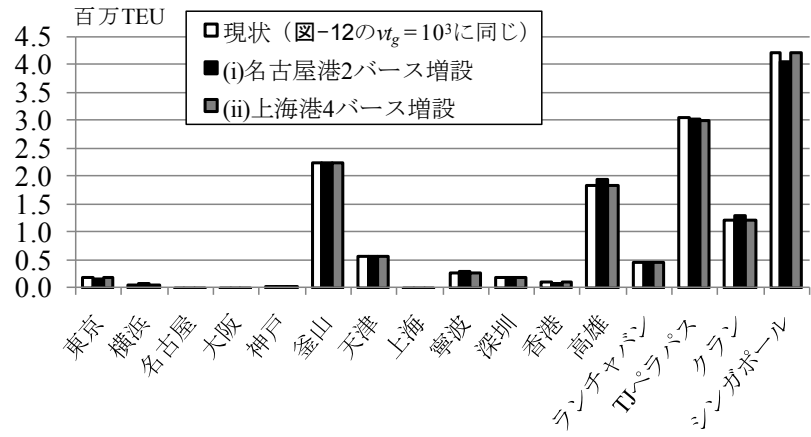

図-16 名古屋港および上海港におけるバース増設に伴う主要 港トランシップ貨物取扱量の変化 $\left(v t_{g}=10^{3}\right)$

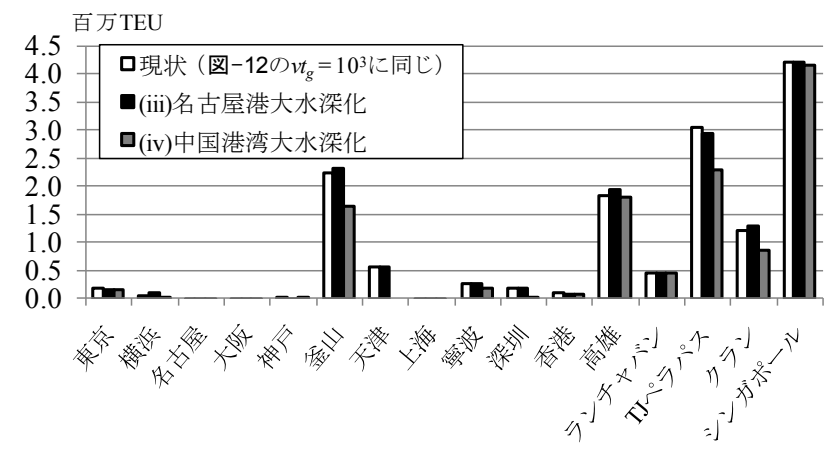

図-17 名古屋港および中国諸港におけるバースの大水深化に 伴う主要港トランシップ貨物取扱量の変化 $\left(v t_{g}=10^{3}\right)$

\section{b) バース大水深化の影響}

a)の比較対照として, 港湾全体のバース数を増加させ ず，水深だけ深くした場合 ${ }^{8}$ の影響をみる. 他のバース に変化はないものとして, (iii)名古屋港, および(iv)中国 本土諸港において，バースの大水深化が進んだケースを とりあげる．具体的には，(iii)については，カテゴリ4の 2バースが，カテゴリ5に増深されたケースを想定する. また(iv)については，現状で水深カテゴリ 5 (最大水深) のバースが存在しない港湾（大連，青島，上海，厦門） について, 既存の最大水深バース（大連，厦門はカテゴ リ3，その他はカテゴリ4）が，すべてカテゴリ5となっ たケースを想定する.

図-17に，各ケースにおける，主要港のトランシップ 貨物量の変化を示す。図より, 特に(iv)のケースでは, 釜山，TJペラパス，クラン港等におけるトランシップ貨 物量が減少する. これは, 中国本土の各港にダイレクト に輸送される貨物が増えるためと考えられる．また，総 輸送費用については，(iii)で名古屋港発着貨物の総輸送 費用が $1.2 \%$ 減少し，(iv)で中国本土発着貨物の総輸送費 用が $1.7 \%$ 減少した。 これを相手国の地域別にみると，対

\footnotetext{
${ }^{8}$ 既存バースの増深のほか, 大水深バースの整備に伴い, 水深の浅 い既存バースを別の用途に転用するケースも該当する. ただし， いずれの場合も総バース数は増加しないことから, モデル計算に おいて, 追加的なターミナル費用は生じないと想定する.
} 
アジア域内・域外貨物における輸送費用の平均削減率が (iii)における名古屋港発着貨物で，それぞれ $0.6 \%$ とおび $1.4 \%$ ，(iv)における中国本土発着貨物で， $-0.03 \%$ よび $2.1 \%$ となっており，いずれもアジア域外航路（すなわち, 長距離航路）において，特に大型船就航の恩恵が大きい ことがわかった。なかでも，対欧州貨物の平均削減率が， (iii)・(iv)それぞれにおいて $5.8 \% ， 3.3 \%$ となるなど，中 東・欧州方面の削減率が大きかった。

\section{c) 港湾荷役時間に関する規模の不経済}

式(20)，(22)に含まれる船卸・船積に要する時間 $T U G_{\text {ivg }}$ およびTL $G_{\text {ivg }}$ は，定義式(19a)，(19b)に示されるように，1 隻あたりの積卸個数 $\left(\frac{}{l f a_{i w g}} \cdot c a p_{w} \cdot \frac{X A U_{i w g}}{X A U_{i w g}+X A P_{i w g}}\right)$ が が増加するほど増加し，貨物の港湾内滞在時間が長くな る. また，式(10)，(16)にも同様の式が含まれていること からわかるように，入港・出港リンクコストに含まれる 港湾混雑による船舶の入出港待ち時間も増加する。 さら に，式(18)に示される停泊リンクコストについても，停 泊リンクフローXAP $P_{\text {ivg }}$ の逆関数として定義されてはいる

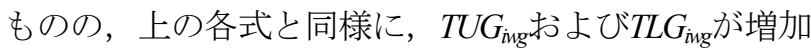
すればコストが増加するという構造となっている.

そこで，荷役時間に関わるパラメータである1クレー
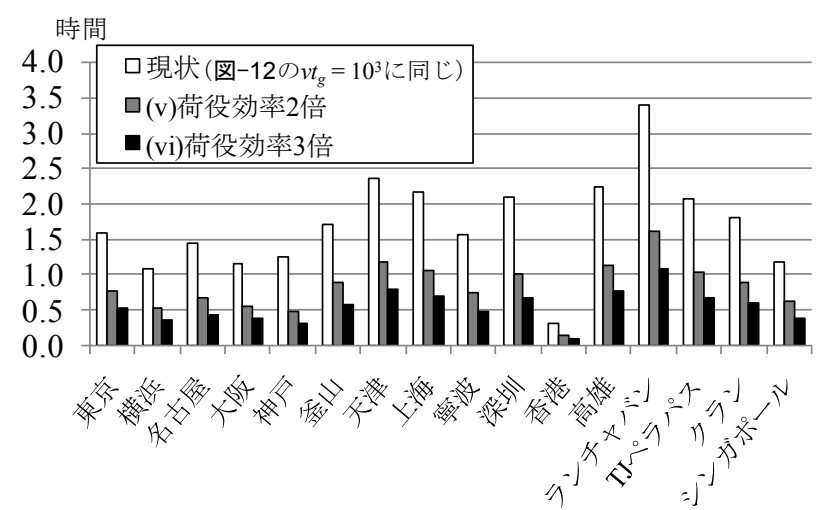

図-18 荷役効率の変化に伴う主要港における 1隻あたり平均 積卸時間の変化 $\left(v t_{g}=10^{3}\right)$

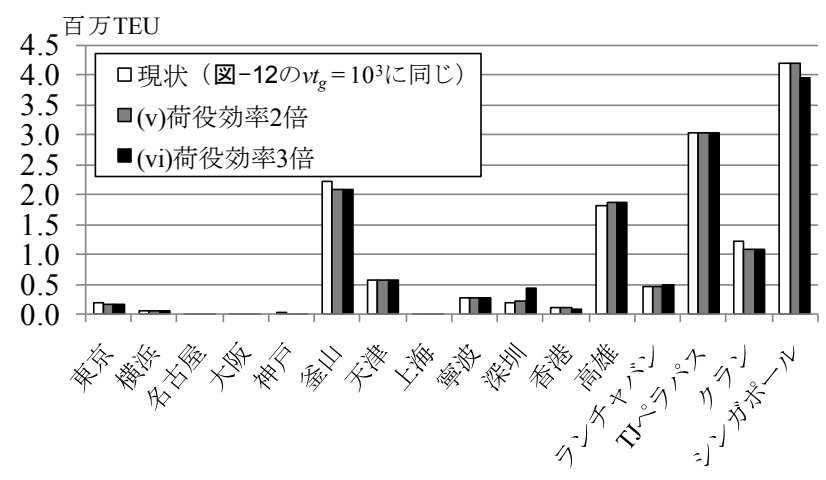

図-19 荷役効率の変化に伴う主要港トランシップ貨物取扱量 の変化 $\left(v t_{g}=10^{3}\right)$

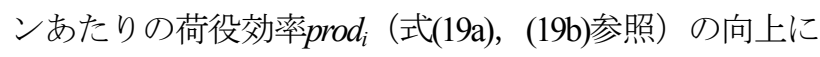

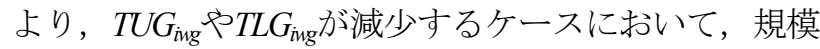
の不経済がどの程度緩和されるかについて検証する，具 体的には，(v)荷役効率2倍，(vi)荷役効率3倍としたケー スと，現状を比較する. 図-18に，各ケースにおける， 主要港の平均荷役時間（船社，サイズ，船卸・船積の加 重平均）の比較を示す．図に示されるように，いずれの 港湾においても，(v)で50\%前後の減少，(vi)で60-70\%の減 少となっており, 荷役効率の向上と荷役時間の減少が, ほぼ反比例の関係になっていることがわかる。一方で， 図-19に示されるトランシップ取扱量の変化をみると, 多少の変動は観察されるものの, 荷役効率が変化しても トランシップ取扱量への影響は小さいことがわかる.

\section{7. 結論}

本研究は，大規模な国際海上コンテナ輸送ネットワー クに適用可能となることを念頭に，各港湾の水深別バー ス数や, 1ターミナルあたりの取扱量の増加に伴う単位 貨物あたりの港湾費用の䢟減効果といった規模の経済, 入出港船舶の集中による混雑や荷役時間の増大といった 規模の不経済を明示的に考慮した，外航船社の費用最小 化モデルを構築した．また，構築したモデルを，東アジ アを中心とした50港からなる国際海上コンテナ輸送ネッ トワークに適用し，モデルの収束状況や再現性の確認を 行った上で, 定式化したこれら規模の経済・不経済がモ デルの出力結果に及ぼす影響について, 感度分析を行っ た．その結果，モデルの振る舞いは概衫妥当であり，規 模の経済・不経済に関連する感度分析の結果も, 概叔想 定した通りの反応であった.

本研究において構築したモデルは，国際海上コンテナ の海上および港湾内輸送に関わる様々な費用や時間要因 を包含し, 航路別のロードファクターや運航頻度, 利用 船舶サイズ，寄港地および積替港という外航船社の様々 な決定変数を内生化した，包括的なモデルといえる．こ のように多様な変数を含み, かつ大規模なモデルにも関 わらず，各変数の感度が概ね妥当であることを確認でき たことで，今後，たとえば，各港湾において様々な施策 が同時に実施された場合の影響シミュレーションを行う， といった実用的ニーズに対応することが可能になるもの と考える.もちろん，各港湾の取扱量をはじめとするモ デル再現精度の向上や，船社の利潤最大化行動や荷主の 行動を包含したモデルの構築も必要である. この点につ いては，別稿13)参照されたい，また，2.で述べたよう に，本モデルにおいては，大規模ネットワークへの適用 を念頭に置き，コンテナの最適化を優先したため, 船舶 (配船）の最適化については十分に考慮されていない, 
という点が比較的大きな課題として残されており，今後 よく検討していきたいと考えている.

\section{付録 $\mathrm{A}$ 入出港リンクの待ち時間 $\varphi\left(N V A_{i w}, T U_{i w}, N B_{i u}{ }^{-1}\right)$ の計算方法}

3.(3)で述べたように，入港リンク・出港リンクにおい ては，バースの水深カテゴリとサイズ別に設定されるコ ス卜関数が， 1 対 1 には対応しない. この関係を，2 種 類の船舶サイズおよびバース水深カテゴリを例に，図一 A1 に模式的に表す．図に示す状況において，大型バー ス $L$ の方が，小型バース $S$ よりも相対的に混雑している 場合 $\left(\frac{N V A_{i L} \cdot T U_{i L}}{N B_{i L}}>\frac{N V A_{i S} \cdot T U_{i S}}{N B_{i S}}\right)$ には, 大型船は大型バ 一ス，小型船は小型バースに入港するため，それぞれの バース処理能力は, 以下のように表される.

$$
\begin{aligned}
& \varphi_{L}\left(N V A_{i L}, T U_{i L}, N B_{i L}{ }^{-1}\right)=\frac{N V A_{i L} \cdot T U_{i L}}{N B_{i L}} \\
& \varphi_{S}\left(N V A_{i S}, T U_{i S}, N B_{i S}{ }^{-1}\right)=\frac{N V A_{i S} \cdot T U_{i S}}{N B_{i S}}
\end{aligned}
$$

一方で，小型バースの方が相対的に混雑している場合 $\left(\frac{N V A_{i L} \cdot T U_{i L}}{N B_{i L}}<\frac{N V A_{i S} \cdot T U_{i S}}{N B_{i S}}\right)$ は, 混雑が均等化されるよ うに，一定割合 $\alpha$ の小型船が大型バースを利用し，結果 として両バースの混䧱待ち時間は等しくなる. 寸なわち,

$$
\begin{gathered}
\varphi_{L}\left(N V A_{i L}, T U_{i L}, N B_{i L}{ }^{-1}\right)=\left(N V A_{i L}+\alpha \cdot N V A_{i S}\right) \cdot \frac{T U_{i L}}{N B_{i L}} \\
\varphi_{S}\left(N V A_{i S}, T U_{i S}, N B_{i S}{ }^{-1}\right)=(1-\alpha) \cdot N V A_{i S} \cdot \frac{T U_{i S}}{N B_{i S}} \\
\varphi_{L}=\varphi_{S}
\end{gathered}
$$

より $\alpha$ を消去して，

$$
\varphi_{L}=\varphi_{S}=\left(N V A_{i L}+N V A_{i S}\right) \cdot \frac{T U_{i L}+T U_{i S}}{N B_{i L}+N B_{i S}}
$$

となる.

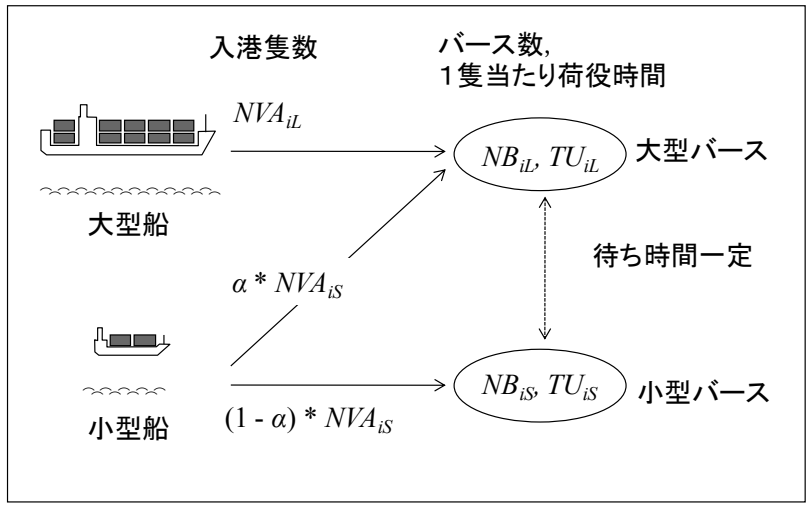

図-A1 バース水深と入港待ち混雑の関係
土木学会論文集D3 (土木計画学), Vol. 67, No. 4, 475-494, 2011.

船舶サイズのカテゴリ数が 3 以上の場合は，より複雑 な手順が必要となる，以下では入港リンクを例に，計算 手順を示寸. 港 $i$ の水深カテゴリ $u(\in U)$ におけるバ 一ス数を, $N B_{u l}$ とする. また, 港 $i$ の船舶サイズカテゴ リ $w$ における，単位時間あたりの入港隻数を $N V A_{i w}$ 一 隻あたりの船卸荷役時間を $T U_{i w}$ としたとき，船舶サイ ズ $w$ の総船卸荷役時間 $T T U_{i w}$ は, $N V A_{i w} \cdot T U_{i w}$ で表される. 基本的な計算の方針としては，小型バースから大型バ 一スに向かって計算を行い，当該サイズ以下のバース混 雑度（合計バース数 $N B S_{u l}$, 総船卸荷役時間 $T T U S_{u l}$ ) と, 当該サイズより大きなバースの混雑度（合計バース数 $N B L_{i u l}$, 総船卸荷役時間 $\left.T T U L_{\dot{u} u}\right)$ を比較し, 前者が後者 を上回る場合は，小型船が大型バースを利用することに よって混雑が均等化するのに対し，後者が前者を上回る 場合は，大型船は小型バースを利用できないので，両者 の混雑度に変化はなく, 大型バースの方が混雑した状況 のまま次のサイズのバースに移る，というものである.

Step 0（計算準備）

計算を開始する水深カテゴリを US とする. 初期状 態においては, $U S=1$ である.

Step 1 (小型バースのバース数，および総船卸荷役時間 の計算)

$u=U S, \quad w=U S, N B S_{i u}=N B_{i u}, \quad T T U S_{i u}=T T U_{i w}$ とおく.

Step 2 (小型バースのバース数が 0 の場合の処理 : 計算 対象水深カテゴリの引き上げ)

$N B S_{u t}=0$ のとき, $u^{\prime}=u, u=u+1, w=w+1$ として,

$N B S_{u t}=N B_{u}, T T U S_{u u}=T T U_{i v}+T T U S_{u t}$ とおく. このステ ップを, $N B S_{\text {ul }}>0$ となるまで繰り返す.

Step 3 (大型バースのバース数，および総船卸荷役時間 の計算)

$N B L_{i u}=\sum_{u^{\prime}=u+1}^{|U|} N B_{i u^{\prime}}, \quad T T U L_{i u}=\sum_{w^{\prime}=u+1}^{|W|} T T U_{i w^{\prime}}$ とする.ただし， $u+1>U$ の場合（計算対象水深カテゴリが最大水深 のとき）は， $N B L_{\dot{u}}=0$ とする.

Step 4 (大型バースのほうが相対的に混雑している場合 の処理 : 小型バースの混雑度を確定し, 次の計算

へ) $\mathrm{Step} 3$ において $N B L_{i u}>0$ のとき, $\frac{T T U S_{i u}}{N B S_{i u}}$ と $\frac{T T U L_{i u}}{N B L_{i u}}$ を 比較し, $\frac{T T U S_{i u}}{N B S_{i u}} \leq \frac{T T U L_{i u}}{N B L_{i u}}$ のとき,

$\varphi_{w}\left(N V A_{i w}, T U_{i w}, N B_{i u}^{-1}\right)=\frac{T T U S_{i u}}{N B S_{i u}} \quad, \quad w=U S, \cdots, u ，$ $U S=u+1$ として, Step 1へ戻る.

Step 5 (小型バースのほうが相対的に混雑している場合 の処理 : 計算対象水深カテゴリの 1 段階引き上げ) Step 4 において $\frac{T T U S_{i u}}{N B S_{i u}}>\frac{T T U L_{i u}}{N B L_{i u}}$ のとき, $u^{\prime}=u$, $u=u+1, \quad N B S_{i u}=N B_{i u}+N B S_{u l}, \quad T T U S_{i u}=T T U_{i w}+T T U S_{u i^{\prime}}$ と 
して, Step3へ戻る.

Step 6 （当該港における最大水深カテゴリにおける処 理 : 終了処理)

Step 3 において $N B L_{\dot{u} u}=0$ のとき，

$\varphi_{w}\left(N V A_{i w}, T U_{i w}, N B_{i u}^{-1}{ }^{-1}\right)=\frac{T T U S_{i u}}{N B S_{i u}}, \quad w=U S, \cdots, u$

$\varphi_{w}\left(N V A_{i w}, T U_{i w}, N B_{i u}{ }^{-1}\right)=\infty, \quad w=u+1, \cdots,|W|$

として終了.

\section{付録 B ロードファクター $l_{\mathrm{vg}}$ の推計方法}

出発港 $i$, 到着港 $j$, 船舶サイズ $w$, 船社 $g$ の航走リン ク $v(=\ddot{j} w)$ における消席率 $l_{\mathrm{vg}}$ （航走 I $\sim \mathrm{IV}$ リンク共 通）は，この 4 種類の航走リンクコストの合計が最小と なるように，各vについて決定されるものと仮定する. すなわち,

$$
\begin{gathered}
\min _{l f_{v g}}\left(\sum_{m} X C_{m v g} \cdot G C_{m v g}\right) \\
\text { s.t. 式(2)および } \\
0.1 \leq l f_{v g} \leq 0.9
\end{gathered}
$$

制約条件(B2)は，消席率が，あまり現実的でない值とな らないための条件である．特に上限值については，貨物 需要の変動や空コンテナの積載が必要であることを考慮 し，1.0ではなく 0.9 としている.

$$
\text { ここで，式(B1)の } l_{\text {g }} \text { についての一階条件を解けば, }
$$

$$
l f_{v g}=\frac{\sum_{m} X C_{m v g}}{\operatorname{cap}_{w}} \cdot \sqrt{\left(\frac{C R_{w g}}{v t_{g}} \cdot \frac{l_{i j}}{v l_{w}}\right) / \sum_{m}\left(\frac{\beta_{m}}{2} \cdot X C_{m g}\right)}
$$

を得る. 式(B3)より得られる $l_{\text {yg }}$ が制約条件(B2)を満たさ ない場合は, $l l_{\mathrm{vg}}=0.1$ または $l_{\mathrm{vg}}=0.9$ が解となる.

なお，厳密に各航路の最適消席率を求めるためには， 航走リンク以外の，コスト関数に消席率が含まれるリン ク（入出港リンク，停泊・船卸・船積リンク）のコスト も含めて，費用が最小となる消席率を計算する必要があ る.また，システム最適均衡配分の求解過程で必要とな るコスト関数の微分計算においても，厳密には，消席率 を含むコスト関数式に対し式(B3)を代入してから，行う 必要がある.しかしながら，これらの計算は非常に煩雑 になるため，本研究のモデル計算では行わない，したが って，上記の計算は，各コス卜関数式において，消席率 を外生的に（たとえば，一律に同じ数值を）与えるより はましな手段として，便宜的に推計を行っているものと 解釈されたい.

\section{参考文献}

1) Containerisation International March 2009, Informa plc., p.40.

2) 国土交通省港湾局 HP : スーパー中枢港湾プロジェク トの推進, http://www.mlit.go.jp/kowan/nucleus_harbor/ nucleus harbor2.html.

3) Christiansen, M., Fagerholt, K., Ronen, D. : Ship Routing and Scheduling: Status and Perspectives, Transportation Science, Vol.38, No.1, pp.1-18, 2004.

4) Christiansen, M., Fagerholt, K., Nygreen, B., Ronen, D. : Maritime Transportation, in Transportation, Handbook in Operations Research and Management Science Vol. 14, North Holland, Chapter 4, pp.189-284, 2007.

5) Ng, A. K. Y., Kee, J. K. Y. : The Optimal Ship Sizes of Container Liner feeder Services in Southeast Asia: A Ship Operator's Perspective, Maritime Policy and Management, Vol.35, No.4, pp.353-376, 2008.

6) Hsu, C. I., Hsieh, Y. P. : Shipping Economic Analysis for Ultra Large Containership, Journal of the Eastern Asia Society for Transportation Studies, Vol.6, pp.936-951, 2005.

7) Agarwal, R., Ergun, O. : Ship Scheduling and Network Design for Cargo Routing in Liner Shipping, Transportation Science, Vol.42, No.2, pp.175-196, 2008.

8) 竹林幹雄, 黒田勝彦, 金井仁志, 原進悟 : グローバ ル・アライアンス間の競争を考慮した国際コンテナ 貨物輸送市場モデルの開発とその適用，土木学会論 文集，No.800/IV-69，pp.51-66，2005.

9) 新谷浩一, 今井昭夫, 西村悦子: 空コンテナの回送 を考慮したコンテナ船のロケーション・ルーチング 問題, 日本航海学会論文集，第 111 号，pp.273-284, 2004.

10) Haralambides, H. E. : Structure and Operations in the Liner Shipping Industry, in Handbook of Transport Modelling (2nd ed.), Elsevier, Chapter 40, pp.761-775, 2008.

11) 家田仁, 柴崎隆一, 内藤智樹, 三島大輔 : アジア圈 国際コンテナ流動モデルの構築とその配分仮説に応 じた特性分析, 土木計画学研究・論文集, No.15, pp.469-480, 1998.

12) Shibasaki, R., Ieda, H., Watanabe, T. : An International Container Shipping Model in East Asia and Its Transferability, in Global Competition in Transportation Markets Analysis and Policy Making (Kanafani and Kuroda ed.), Research in Transportation Economics Vol.13, Elsevier, pp.299-336, 2005.

13）柴崎隆一, 渡部富博, 家田仁 : 船社・荷主の最適行 動を考慮した国際海上コンテナ輸送の大規模シミュ レーション，土木学会論文集 $\mathrm{D} 3$ ，掲載決定済

14) Harker, P. T. : Multiple Equilibrium Behaviors on Networks, Transportation Science, Vol.22, No.1, pp.39-46, 1988.

15) Yang, H., Zhang, X., Meng, Q. : Stackelberg Games and Multiple Equilibrium Behaviors on Networks, Transportation Research Part B, Vol.41, No.8, pp.841-861, 2007.

16）港湾事業評価手法に関寸る研究委員会編：港湾投資 の評価に関する解説書2004, (財)港湾空間高度化環境 研究センター.

17) 土木学会土木計画学研究委員会「交通ネットワー ク」出版小委員会: 交通ネットワークの均衡分析 一最新の理論と解法一, 土木学会, 331p, 1998. 
18）国土交通省港湾局：平成 15 年度全国輸出入コンテナ 貨物流動調査, 2003 .

19）日本航海士会編：世界港間距離図表（二訂版），海 文堂, 1993.

20) Seafuture, Inc. : Netpas Distance, 2007.

21）黑川久幸, 鶴田三郎, 嶋邦彦 : 海上コンテナ輸送ネ ットワークの設計に関する研究一東・東南アジアの 中心として一, 日本航海学会論文集, Vol.101, pp.259-269, 1999.

22) 森浩. 石川浩章, 川上泰司：外貿コンテナ輸送コス トモデルの開発, 土木計画学研究・講演集, Vol.17, pp.1075-1078, 1995.

23) World Bank: Doing Business -Measuring business regulations- http://www.doingbusiness.org/（2009 年 5 月 12 日 接続)
24) Informa UK Ltd. : Containerisation International Yearbook 2005（および各年版）, informa trade \& energy.

25) MDS Transmodal Ltd. : MDS Containership Databank November 2003.

26) Dimaranan, B. V., Ed. : Global Trade, Assistance, and Production: The GTAP 6 Data Base, Center for Global Trade Analysis, Purdue University, 2006.

27) Shibasaki, R., Yonemoto, K., Watanabe, T. : On the effects of trade liberalization policies on regional economies based on "Transnational Interregional Input-Output Table between China and Japan", 11th Annual Conference on Global Economic Analysis, Helsinki, Finland, 2008.

28) IHS Global Insight Inc. : Global Trade navigator.

(2010.8.19 受付)

\section{COST MINIMIZATION MODEL OF OCEANGOING CARRIERS ON A LARGE-SCALE INTERNATIONAL MARITIME CONTAINER SHIPPING NETWORK CONSIDERING CHARACTERISTICS OF PORTS}

\section{Ryuichi SHIBASAKI, Tomihiro WATANABE and Hitoshi IEDA}

This paper deals with a cost minimization problem of oceangoing carriers on a large-scale network of international maritime container shipping industry, in order to measure impact of port policies for each country including Japan. Concretely, the authors develop a model to decide ports to call and size of containership in each route by ocean-going carrier group, with consideration of construction of deeper berths to deal with enlargement of containership, decrease of various port charges per cargo by attracting cargos into one port, and congestion by exceeding aggregation.

The developed model is applied to the actual large-scale international maritime container shipping network in Eastern Asia. The performance of the model developed is validated. Also, the sensitivity of the model output is confirmed from the viewpoints of economy and diseconomy of scale included in the model. 